\title{
Effect of different feeding strategies in intensive dairy farming systems on milk fatty acid profiles, and implications on feeding costs in Italy
}

\author{
G. Borreani, ${ }^{\star}$ M. Coppa, ${ }^{\star 1}$ A. Revello-Chion, $\dagger$ L. Comino, ${ }^{*}$ D. Giaccone $\nmid \dagger$ A. Ferlay, $₫ \S$ and E. Tabacco* \\ *University of Turin, Department of Agricultural, Forest and Food Sciences, Via L. da Vinci 44, 10095, Grugliasco (Turin), Italy \\ †Associazione Regionale Allevatori del Piemonte, Via Livorno 60, 10144, Turin, Italy \\ fINRA, UMR 1213 Herbivores, F-63122 Saint-Genès-Champanelle, France \\ §Clermont Université, VetAgro Sup, UMR Herbivores, BP 10448, F-63000 Clermont-Ferrand, France
}

\begin{abstract}
The aim of this work was to characterize the fatty acid (FA) profile of milk from intensive dairy farming systems in the Po Plain (Italy) to estimate the costs of the adopted feeding strategies and to simulate the effect of supplementary premiums on the basis of milk FA composition on milk income. Twenty dairy farms with 5 different feeding strategies were studied: 3 corn silage-based systems in which cows were supplemented with a great proportion $(\mathrm{CCH})$, a medium proportion (CCM), or without commercial concentrate mix (CC0), and 2 systems in which part of corn silage was replaced with grass or legume silage (HF) or with fresh herbage $(\mathrm{G})$, cut and fed indoors. Bulk milk was sampled and lactating cow performance, feeding strategies and forage characteristics were recorded through a survey, 3 times during a year. The milk FA supplementary premium was calculated considering C18:3n-3 and saturated FA (SFA) concentrations, and ratio of total cis C18:1 isomers to $\mathrm{C} 16: 0$. The $\mathrm{CCH}, \mathrm{CCM}$, and $\mathrm{CC} 0$ systems bought most of their dairy cow feeds off farm, which allowed them to increase milk production to $35,000 \mathrm{~L} /$ yr per hectare. Their low dry matter and crude protein self-sufficiency led to higher feeding costs per liter of milk (from €0.158 to €0.184), and highest income over feed cost was achieved only for milk yield performance greater than $10,000 \mathrm{~kg} / \mathrm{cow}$ per year. The use of homegrown forages in HF and $\mathrm{G}$ increased dry matter and crude protein self-sufficiency and reduced the feeding costs per liter of milk from 9 to $22 \%$, compared with the other studied systems, making HF and G feeding economically competitive, even for a lower milk yield per cow. The studied systems highlighted a remarkable variation in FA profiles. The concentrations of C16:0 and SFA were the highest in $\mathrm{CCH}$ (31.53 and 67.84 $\mathrm{g} / 100 \mathrm{~g}$ of FA) and $\mathrm{G}(31.23$ and $68.45 \mathrm{~g} / 100 \mathrm{~g}$ of FA), because of the larger proportion of commercial concen-
\end{abstract}

Received February 19, 2013.

Accepted July 8, 2013.

${ }^{1}$ Corresponding author: mauro.coppa@unito.it trate mix in the cow diet. The concentrations of $\mathrm{C} 16: 0$ and SFA were the lowest in CCM (27.86 and 63.10 $\mathrm{g} / 100 \mathrm{~g}$ of FA), because of low roughage-to-concentrate ratio in the cow diet, which is known to favor milk fat depression, affecting particularly these FA. The calculated supplementary premium was the highest in the CCM system, based on milk FA profiles from those herds. The HF diet was rich in forages and resulted in greater concentration of $\mathrm{C} 18: 3 \mathrm{n}-3$ in milk $(0.57 \mathrm{~g} / 100$ $\mathrm{g}$ of FA) than the other systems and thus led to an increase in milk FA supplementary premium. Milk from G and HF milk had the lowest ratio of $\Sigma n-6: \Sigma n-3$ FA compared with milk from the systems based on higher corn silage proportion in the cow diet (3.71, and 3.25, respectively, vs. 4.58 to 4.78 ), with the lower ratios being closer to recommendation for human nutrition.

Key words: milk fatty acid, intensive farming system, feeding costs, milk fatty acid supplementary premium

\section{INTRODUCTION}

The demand for dairy products with a great nutritional value has recently increased. Some milk FA, such as $\mathrm{C} 18: 2 \mathrm{n}-6$ and $\mathrm{C} 18: 3 \mathrm{n}-3$, are essential because they cannot be synthesized by the human body (Stark et al., 2008). In recent years, the consumption of $n-6$ FA, such as linoleic acid, has risen dramatically in developed nations (Stark et al., 2008). Over the last decade, several studies have highlighted cow feeding as the main factor of influence on milk FA composition (Dewhurst et al., 2006; Chilliard et al., 2007). However, the majority of these studies have been conducted in controlled conditions, in which contrasted and extreme diets were compared (Ferlay et al., 2006; Coppa et al., 2011a; Sterk et al., 2011). Only a few studies have been carried out at farm level, and most of them have been focused on mountain farming systems (Collomb et al., 2002; Lucas et al., 2006; Ferlay et al., 2008), or on organic farming systems (Butler et al., 2008; Slots et al., 2009), in which diets based on pasture and conserved grass feeding were the most common feeding strategies. However, little is known about the intensive farming systems that are 
based on corn silage feeding or about the variations in FA composition of such milk, due to varying feeding strategies (Slots et al., 2009). Some experimental studies using corn-based diets have shown that milk from such systems has about 10 to $15 \mathrm{~g} / 100 \mathrm{~g}$ of FA more of SFA; about double the amount of n-6 FA, with $25 \%$ less PUFA; and only 33 to $50 \%$ of the amount of n-3 FA as found in pasture-derived milk (Ferlay et al., 2006; Sterk et al., 2011).

Pasture-based farming systems are widely diffused in the European countries with great milk production (i.e., France, Germany, and the Netherlands, among others). Italy produces about 10 million metric tonnes of milk per year, which represents substantial proportion of the milk production in the European Union 15 (EU-15; CLAL S.r.l., 2013). However, the milk obtained from pasture-based farming systems in Italy is negligible on a national scale. About $80 \%$ of Italian milk comes from intensive farming systems located in the Po Plain, where the high-yielding Italian Holstein breed is raised. There is a scarcity of arable land in the Po Plain and land charge/rent is high. However, soil fertility and the climate are favorable for crops such as corn silage with high DM yield potential per hectare. As a consequence, most dairy farms have specialized in corn silage production, with the aim of being selfsufficient for the animals' energy requirements, but buy most of the protein sources from the market. This has led to an extreme simplification of the dairy forage system, with corn silage representing up to $90 \%$ of the total roughage in lactating cow diets, and concentrates representing from 30 to $55 \%$ of total DM in the cow diet. Two different strategies are diffused in Italy to supply protein for lactating cows: buying directly from the market raw materials (e.g., soybean and rapeseed meals) or buying commercial concentrate mixes from specialized companies. This second feed supply seems much simpler to manage for farmers, but it requires a preparation step in specialized companies and this implies greater prices for concentrates.

Recent volatility in corn and soybean market prices has resulted in increased uncertainty about concentrate costs and thus the corn silage-based dairy farming system no longer seems to be economically sustainable. Therefore, to maintain farm competitiveness, a decrease in feeding costs is needed (Wolf, 2012). As a consequence, feeding strategies based on greater selfsufficiency in the production of cow feeds are spreading in the Po Plain; this is achieved by increasing the proportion of conserved forages with great nutritional quality in the lactating cow diet, or by introducing fresh herbage, cut and fed indoors. Another strategy to maintain economic efficiency of the intensive dairy farms in the Po Plain could be increasing the milk price through a valorization of milk FA profile. Recently some European countries (such as France and the Netherlands) have introduced supplementary premiums for farmers, based on FA composition of milk and, in particular, on SFA, n-3 FA, total C18:1 FA, C18:3n-3, cis-9 C18:1, and $\mathrm{C} 16: 0$.

The main aim of this work was to characterize the FA composition of the milk produced in the different intensive dairy farming systems of the Po Plain, Italy. The second aim was to estimate the costs of feeding strategies adopted in these farming systems and to simulate the effect of supplementary premiums, based on milk FA composition, on milk income.

\section{MATERIALS AND METHODS}

\section{Experimental Design, Milk Sampling, and Data Collection}

The research was conducted in the lowland area (about $250 \mathrm{~m}$ above sea level) of the Piedmont Region, in northwestern Italy. Twenty dairy farms raising Italian Holsteins, which adopted 5 different feeding strategies (4 farms per group) were selected to be representative of the intensive farming systems of northern Italy. Three of the 5 farming systems were selected according to the proportion of commercial concentrate mix fed to lactating cows: great proportion $(\mathbf{C C H})$, medium proportion $(\mathbf{C C M})$, or no commercial concentrate mix in cow feeding (CC0). The commercial concentrate mix was replaced by increasing proportions of soybean meal and other single raw concentrates. The first 3 systems all used corn silage as the main component of the diet. The fourth and the fifth systems replaced part of the corn silage in the cow diet with grass or legume (mainly alfalfa) silage (HF) or with fresh herbage $(\mathbf{G})$, cut and fed indoors. Bulk milk samples were collected 3 times on each farm [June to July 2011 (period 1, P1), November to December 2011 (period 2, P2), and February to March 2012 (period 3, P3)]. During each milk sampling, the performance of lactating cows and herd characteristics (number of cows, DIM, and milk yield), feeding strategies (forage source), and forage characteristics (harvesting and conservation methods, cutting dates, and cropping agronomic management) were recorded through a detailed survey made directly on farm by the authors. Corn silage contains great proportions of starch because of its grain, even though it is considered a forage in protected designation of origin (PDO) specifications. For these reasons, the total concentrate and roughage were calculated in 2 ways: considering corn silage (1) as roughage and (2) $40 \%$ of DM as a concentrate and $60 \%$ as roughage, as proposed by Mertens (2009). To highlight the role of 
conserved forages derived from grasslands, the sum of hay and grass or legume silage was presented as "total grassland-derived conserved forage." Corn and barley flours and flakes were considered together as "other starch-rich concentrates," and rapeseed and sunflower seed meals were considered together as "other proteinrich concentrates." The several other concentrates that were irregularly present in the diet of the studied farm (never exceeding 10\% of the daily DMI) were grouped together as follows: brewers grain, distiller, rice husk, beet pulp, bran, and cane molasses were considered together as "other concentrates"; whole linseeds, sunflower seeds, and cottonseeds as "oilseeds"; and commercial mix of fat, based mainly on palm oil, as "fat" supplement. The "commercial concentrate mixes" were composed of variable proportions of all the previously cited raw material and by other byproducts from cereal processing, and may also have included lipid supplements (mainly palm oil) in variable amounts.

\section{Feed Sampling and Analysis}

A sample (about $0.5 \mathrm{~kg}$ ) of TMR was collected at each milk sampling, oven dried at $60^{\circ} \mathrm{C}$ to constant weight to determine the DM content, and then air equilibrated, weighed, and ground in a Cyclotec mill (Tecator Inc., Herndon, VA) to pass a 1-mm screen. Dried samples were analyzed for $\mathrm{CP}$ (total $\mathrm{N} \times 6.25$ ) by combustion (Micro-N nitrogen analyzer; Elementar Analysensysteme GmbH, Hanau, Germany), for ash by ignition to $550^{\circ} \mathrm{C}$ for $3 \mathrm{~h}$, for NDF using the sulfite and amylase method (Van Soest et al., 1991), for ether extract (EE) by ether extraction, and for starch concentration according to the AOAC International method (AOAC International, 2005).

\section{Milk Analyses}

Bulk milk was sampled directly from each farm tank and then stored at $4^{\circ} \mathrm{C}$ and transported to the laboratory. Each milk sample was divided into 2 subsamples. Milk fat, protein, lactose, urea, and casein contents were measured on a subsample by means of Fouriertransform infrared spectroscopy (MilkoScan FT6000; Foss Electric A/S, Hillerød, Denmark). The SCC and total bacteria counts (TBC) were automatically determined in the same subsamples by the mean of Fossomatic FC (Foss Electric A/S), and BactoScan FC (Foss Electric A/S), respectively. The other subsample was centrifuged $3,700 \times g$ for $15 \mathrm{~min}$ at $4^{\circ} \mathrm{C}$ to separate the cream. The cream was centrifuged $20,000 \times g$ for $35 \mathrm{~min}$ at $35^{\circ} \mathrm{C}$. The supernatant anhydrous fat was separated and analyzed directly for FA. The FA transesterification was obtained using $2 M$ sodium methylate to start and sodium sulfate monohydrate to stop the methylation processes, according to Revello-Chion et al. (2010). The FA methyl esters were analyzed by gas chromatography as described by Coppa et al. (2011a). Briefly, samples were injected into a 7890A GC-System (Agilent Technologies Inc., Santa Clara, CA) gas chromatograph equipped with a flame ionization detector. The FA methyl esters were separated on a $100-\mathrm{m} \times$ 0.25-mm i.d. fused-silica capillary column (CP-Sil 88; Chrompack Nederland BV, Middelburg, the Netherlands). The injector temperature was maintained at $250^{\circ} \mathrm{C}$ and the detector temperature at $255^{\circ} \mathrm{C}$. The initial oven temperature was held at $70^{\circ} \mathrm{C}$ for 1 min, which was then increased by $5^{\circ} \mathrm{C} / \mathrm{min}$ to $100^{\circ} \mathrm{C}$ (held for 2 $\min$ ), followed by $10^{\circ} \mathrm{C} / \mathrm{min}$ to $175^{\circ} \mathrm{C}$ (held for $40 \mathrm{~min}$ ), and then increased by $5^{\circ} \mathrm{C} / \mathrm{min}$ to a final temperature of $225^{\circ} \mathrm{C}$ (held for $15 \mathrm{~min}$ ). The carrier gas was hydrogen. The trans C18:1 isomers, nonconjugated 18:2 FA, and conjugated linoleic acid (CLA) isomers were identified as described in Loor et al. (2005). A reference standard butter (CRM 164; Commission of the European Communities, Community Bureau of Reference, Brussels, Belgium) was used to estimate correction factors for short-chain FA (C4:0 to C10:0).

\section{Farm Efficiency Parameters and Milk FA Supplementary Premiums}

The standard contractor charges and material costs (seeds, fertilizers, and crop chemicals) were used for all the operations and materials to calculate homegrown feed (ensiled forages or grain) costs. The operator labor, diesel fuel and oil usage, depreciation, repairs, maintenance, insurance for the implements and tractors, and interest on operating capital were taken into account by using contractor charges. The budget also included crop production and storage costs. The average market prices of the September 2011 to August 2012 period were taken into account for all the purchased feeds (including vitamins and minerals). All feed costs were calculated after converting feeds to a zero moisture level. Labor costs for feeding operations and land charge or land rent were not included in the calculation. The budget did not include feed costs for the dry cows, heifers, or calves.

Feeding costs were calculated, for each farm and sampling date, as the sum of total costs of feeds and minerals fed daily to all lactating dairy cows (on a DM basis), and were then reported as cost per cow per day. Total feed cost per liter of sold milk was also calculated as the ratio between feeding cost and milk yield per day, as a measure of the effectiveness of management to control the greatest-cost item in producing milk. The value of the produced milk was calculated according 
to the Lombardy regional agreements for 2012, on the basis of milk yield and on component yield and quality (additional value added or deducted on the basis of the amount of protein, fat, and on SCC and TBC score, which was determined twice per month for the milk of each individual farm). In addition, the income over feed costs (IOFC) was calculated by subtracting the cost of the cow ration from milk production income. Feed efficiency was calculated as the ratio between $3.5 \% \mathrm{FCM}$ $(\mathrm{L} /$ cow $\times$ day $)$ and DMI $(\mathrm{kg} /$ cow $\times$ day $)$.

Some other indicators were calculated for each farm and each sampling date: the self-sufficiencies of farm for DM and protein requirements were calculated as the ratio between the amount of feed DM or protein produced on farm and the total amounts of feed DM or protein fed daily to lactating cows.

Two milk FA supplementary premiums were calculated to understand if the application of milk FA supplementary premiums would have led to differences among the studied feeding systems, according to the payment system applied by Valorex SAS (Combourtillé, France; http://www.valorex.com/) and by Danone (Tremblay-en-France, France). Both those premium systems were developed for and are applied in the intensive dairy farming systems of the northwest of France. The Valorex premium was calculated considering (1) the concentration of $\mathrm{C} 18: 3 \mathrm{n}-3,(2)$ the concentration of SFA (excluding C18:0), and (3) total C18:1 isomers-toC16:0 ratio. The premium increased by $€ 0.089 / 1,000 \mathrm{~L}$ of milk for each $0.1 \mathrm{~g} / 100 \mathrm{~g}$ of FA increase in C18:3n-3 concentration and 0.1 point of total cis $\mathrm{C} 18: 1$ isomersto-C16:0 ratio, as well as decreased by $€ 0.089 / 1,000$ $\mathrm{L}$ of milk for each $0.3 \mathrm{~g} / 100 \mathrm{~g}$ of FA increase in SFA (excluding C18:0) concentration. The minimum remunerated values for (1), (2), and (3) were $0.5 \mathrm{~g} / 100 \mathrm{~g}$ of FA, $61 \mathrm{~g} / 100 \mathrm{~g}$ of $\mathrm{FA}$, and 0.7 , respectively, and maximum remunerated values were $1.1 \mathrm{~g} / 100 \mathrm{~g}$ of FA, $43 \mathrm{~g} / 100 \mathrm{~g}$ of FA, and 1.3, respectively. The theoretical FA supplementary premium range was from 0 to $€ 17 / 1,000 \mathrm{~L}$ of milk, to which $€ 2 / 1,000 \mathrm{~L}$ of milk are added to account for the participation in the FA payment system, regardless of the milk FA composition. The Danone premium was calculated considering (1) the concentration of $\mathrm{C} 18: 3 \mathrm{n}-3$, (2) the concentration of even-chain SFA, and (3) the total C18:1 isomers-toC16:0 ratio, whose minimum remunerated FA values were $0.6 \mathrm{~g} / 100 \mathrm{~g}$ of FA, $68 \mathrm{~g} / 100 \mathrm{~g}$ of FA, and 0.7 , and maximum remunerated FA values were $1.2 \mathrm{~g} / 100 \mathrm{~g}$ of FA, $57 \mathrm{~g} / 100 \mathrm{~g}$ of FA, and 1.2 respectively. The premium increased by $€ 8 / 1,000 \mathrm{~L}$ of milk for each $0.1 \mathrm{~g} / 100 \mathrm{~g}$ of FA increase in C18:3n-3 concentration, by $€ 12 / 1,000$ L of milk for every 0.1 point of total C18:1 isomers-toC16 ratio, and decreased by $€ 0.7 / 1,000 \mathrm{~L}$ of milk for 1 $\mathrm{g} / 100 \mathrm{~g}$ of FA increase in even-chain SFA. A threshold of $€ 5 / 1,000 \mathrm{~L}$ of milk was needed to acquire the right to the premium. An additional premium of $€ 5 / 1,000 \mathrm{~L}$ of milk was given if the previously described premium calculation was between $€ 5$ and $€ 9 / 1,000 \mathrm{~L}$ of milk. The additional premium was increased by $€ 7 / 1,000 \mathrm{~L}$ of milk if the previously described premium calculation exceeded $€ 9 / 1,000 \mathrm{~L}$ of milk. As a result, if a farm qualified for a premium, the minimum premium was $€ 10 / 1,000 \mathrm{~L}$ of milk, whereas the maximum premium was set at $€ 20 / 1,000 \mathrm{~L}$ of milk. Those 2 FA supplementary premiums calculations considered SFA and C18:3n-3 parameters because of their implications in human nutrition and health (Kratz et al., 2013), whereas the total C18:1 isomers-to-C16 ratio was considered because of its implication in cheesemaking technology: it is indeed related to the milk fat melting point and thus can affect butter spreadability and cheese texture (Hurtaud et al., 2009; Coppa et al., 2011b).

\section{Statistics}

Statistical analyses were performed using the SPSS for Windows software package (version 17.0; SPSS Inc., Chicago, IL). All the data for lactating herd characteristics, performance, TMR, and milk composition, were processed using the ANOVA repeated-measures model, in which sampling period was the repeated factor, whereas farm system and farm system $\times$ period interaction were the fixed factors. Data about farm efficiency parameters were processed using a general linear model of the ANOVA, in which the farm system was the fixed factor. A principal components analysis (PCA) was performed on the main FA and farming practices data, with the aim of showing the relationship between milk FA profile and production conditions.

\section{RESULTS}

\section{Lactating Herd Feeding}

Data about lactating cow feeding are reported in Table 1. The HF and $\mathrm{G}$ had lower proportion of corn silage than $\mathrm{CCH}$ and $\mathrm{CC} 0(-15.5 \%$ of average daily DMI of the 2 groups), whereas CCM had intermediate values $(-8.2 \%$ of daily DMI). The grass or legume silage proportion in the cow diet in HF was the greatest $(+13.4 \%$ of daily DMI). The hay proportion in the cow diet was greater in $\mathrm{G}$ than in $\mathrm{HF}, \mathrm{CCM}$, and $\mathrm{CCH}$ $(+11.8 \%$ of daily DMI $)$, with intermediate values for the $\mathrm{CC} 0$. Fresh herbage was only present in $\mathrm{G}$, with a mean value of $10.7 \%$ of daily DMI. The soybean meal proportion in the cow diet was lower in G than in CCM, $\mathrm{CC}$, and $\mathrm{HF}$ ( $-4.7 \%$ of daily DMI), and was negligible in $\mathrm{CCH}$. The $\mathrm{CC} 0$ cows were fed a greater proportion 
of other protein-rich concentrates than $\mathrm{HF}(+4.2 \%$ of daily DMI), which were absent in the other systems. The total forage proportion in the cow diet was greater in $\mathrm{HF}$ and $\mathrm{G}$ than in the other systems $(+13.1 \%$ of daily DMI). The proportion of total roughage in $\mathrm{G}$ was greater than in $\mathrm{HF}(+7.6 \%$ of daily $\mathrm{DMI})$ and $\mathrm{CCH}$, $\mathrm{CCM}$, and $\mathrm{CC} 0(+15.1 \%$ of daily $\mathrm{DMI})$, and in $\mathrm{HF}$ than in $\mathrm{CCH}, \mathrm{CCM}$, and $\mathrm{CC} 0(+7.5 \%$ of daily $\mathrm{DMI})$. The hay proportion in the cow diet was greater in P3 than in $\mathrm{P} 1$ and $\mathrm{P} 2(+2.3 \%$ of daily $\mathrm{DMI})$, whereas the opposite trend was observed for grass or legume silage proportion $(-6.0 \%$ of daily DMI). The ensiled ground ear corn proportion in the cow diet was greater in P3 than in $\mathrm{P} 2(+3.4 \%$ of daily $\mathrm{DMI})$, with intermediate values for $\mathrm{P} 1$, whereas an opposite trend was observed for the proportion of other starch-rich concentrates $(-4.6 \%$ of daily DMI). Fresh herbage in $\mathrm{G}$ was lower in P3 than in P1 and P2 (5.2 vs. 13.6 and $13.3 \%$ of daily DMI, respectively).

Results of chemical composition of the diets are given in Table 2. The G diet had greater NDF content than that of the other systems $(-5.47 \%$ of $\mathrm{DM})$ and lower starch and NSC content than $\mathrm{CCH}$ and $\mathrm{CC} 0$ systems (on average, $-4.93 \%$ of $\mathrm{DM}$ and $-6.05 \%$ of $\mathrm{DM}$, respectively). The ash content of the diets was, on average, lower in P3 than in P1 and P2, whereas the EE content was greater in $\mathrm{P} 3$ than in $\mathrm{P} 1$.

\section{Lactating Herd Performance and Characteristics}

The herd size, lactating cow performance, and milk composition data are reported in Table 3 . The HF and $\mathrm{G}$ had, on average, about half the number of lactating cows as the other systems. The $\mathrm{G}$ also had lower milk yield per cow than CCM $(-7.0 \mathrm{~L} /$ cow $\times \mathrm{d})$ and the other systems were intermediate. The milk fat content for CCM was the lowest, and was the greatest for $\mathrm{CCH}$ and $\mathrm{G}$, with intermediate values for $\mathrm{CC} 0$ and $\mathrm{HF}$ $(+0.41,+0.36,+0.27$, and $+0.15 \mathrm{~g} / 100 \mathrm{~g}$ compared with CCM, respectively). No significant differences between systems were found for DIM, milk protein, lactose, casein or urea contents, SSC, and TBC.

The milk yield was lower in P2 than in P3 $(-1.5 \mathrm{~L} /$ cow $\times d)$. The DIM were the greatest in P1 $(+23 \mathrm{~d})$. Milk lactose content was the lowest in P2, whereas milk fat, protein and casein contents were the lowest in P1. No significant interactions were found.

\section{Milk FA Composition}

Data on milk FA composition are reported in Table 4 on the basis of feeding system and sampling period. Lactating herd feeding and sampling period signifi- cantly affected almost all FA, whereas no significant interaction between treatment and period was found.

Even-Chain SFA. Milk from G, HF, and CCH had, in general, greater concentrations of de novo preformed FA through $\mathrm{C} 16: 0$ than milk from the other systems. In particular, $\mathrm{C} 4: 0, \mathrm{C} 6: 0$, and $\mathrm{C} 14: 0$ concentrations were greater in $\mathrm{G}$ than in $\mathrm{CCM}$ and $\mathrm{CC} 0$ milk $(+0.20$, +0.21 , and $+1.03 \mathrm{~g} / 100 \mathrm{~g}$ of FA, respectively), with intermediate values for $\mathrm{CCH}$ and $\mathrm{HF}$ milk. Milk from $\mathrm{G}, \mathrm{HF}$, and $\mathrm{CCH}$ had greater concentrations of $\mathrm{C} 8: 0$ and C12:0 than those from CCM, with intermediate values for $\mathrm{CC}$. The $\mathrm{C} 10: 0$ concentration was greater in $\mathrm{G}, \mathrm{HF}$, and $\mathrm{CCH}$ milk than in $\mathrm{CCM}$ and $\mathrm{CCO}$ milk. The $\mathrm{G}$ milk had the greatest concentration of the sum of de novo preformed FA (sum of C4:0 to C14:0) and the CCM milk had the lowest $(-2.37 \mathrm{~g} / 100 \mathrm{~g}$ of FA).

The $\mathrm{CCH}$ and $\mathrm{G}$ milk had the greatest concentrations of C16:0 and the sum of SFA than CCM and CC0 milk, with intermediate values in $\mathrm{HF}$ milk $(+2.88$, and $+4.26 \mathrm{~g} / 100 \mathrm{~g}$ of FA, respectively), whereas $\mathrm{C} 22: 0$ concentration was lower in $\mathrm{G}$ milk than in $\mathrm{CCM}$ and CC0 milk. The concentrations of $\mathrm{C} 4: 0$ and $\mathrm{C} 10: 0$ in milk were greater in $\mathrm{P} 1$ than in $\mathrm{P} 2$ and $\mathrm{P} 3$, whereas those of C10:0, C12:0, and C14:0 were greater in P3 than in $\mathrm{P} 1$, with intermediate values in $\mathrm{P} 2$.

Odd-Chain SFA. The G milk had lower concentration of C5:0, C7:0, and C9:0 than milk from other systems, whereas no differences among systems were observed for all the other odd-chain SFA, or for their sum. The milk in P3 showed greater concentrations of C5:0, C9:0, C11:0, and C13:0 than in P1, with intermediate values in $\mathrm{P} 2$, whereas $\mathrm{C} 19: 0$ and $\mathrm{C} 23: 0$ were greater in $\mathrm{P} 2$ than in $\mathrm{P} 1$ and $\mathrm{P} 3$.

Branched-Chain $\boldsymbol{F A}$. The branched-chain FA (BCFA) concentration was, in general, greater in $\mathrm{G}$ milk. The anteiso $\mathrm{C} 13: 0$ and anteiso $\mathrm{C} 15: 0$ concentrations were greater in G milk than in CCM milk, with intermediate values for the other milk. The iso $\mathrm{C} 13: 0$ concentration was greater in G milk than in CCM, CC0, and $\mathrm{HF}$ milk, with intermediate values in $\mathrm{CCH}$ milk. The G milk had greater concentration of iso C14:0 than the other milk $(+0.03 \mathrm{~g} / 100 \mathrm{~g}$ of FA), and CCM milk had lower concentration of iso $\mathrm{C} 14: 0$ than $\mathrm{CCH}$ and CC0 milk (-0.02 g/100 g of FA). The iso C15:0 and the sum of BCFA concentrations were greater in $\mathrm{G}$ milk than in all the other milk $(+0.04$ and $+0.20 \mathrm{~g} / 100 \mathrm{~g}$ of FA, respectively).

The iso $\mathrm{C} 13: 0$ and anteiso $\mathrm{C} 13: 0$ concentrations in milk were lower in P3 than in P1 and P2. Greater concentrations of iso C15:0 and iso C16:0 were observed in P1 than in P2 and P3. The milk concentration of anteiso $\mathrm{C} 15: 0$ was lower in $\mathrm{P} 3$ than in $\mathrm{P} 1$, with intermediate values in $\mathrm{P} 2$. 
Table 1. Lactating cow diets according to feeding system and sampling period

\begin{tabular}{|c|c|c|c|c|c|c|c|c|c|c|c|c|}
\hline \multirow[b]{2}{*}{ Ingredient $^{1}$ ( $\%$ of DMI) } & \multicolumn{5}{|c|}{ System $^{2}$} & \multicolumn{3}{|c|}{ Period $^{3}$} & \multirow[b]{2}{*}{ SEM } & \multicolumn{3}{|c|}{ Effect and significance } \\
\hline & $\mathrm{CCH}$ & $\mathrm{CCM}$ & $\mathrm{CC} 0$ & $\mathrm{HF}$ & G & P1 & $\mathrm{P} 2$ & P3 & & System & Period & System $\times$ period \\
\hline Corn silage & $39.1^{\mathrm{a}}$ & $31.8^{\mathrm{ab}}$ & $41.0^{\mathrm{a}}$ & $24.5^{\mathrm{b}}$ & $24.4^{\mathrm{b}}$ & 31.0 & 30.2 & 35.2 & 1.53 & ** & NS & NS \\
\hline Grass or legume silage & $9.3^{\mathrm{b}}$ & $6.6^{\mathrm{b}}$ & $2.3^{\mathrm{b}}$ & $19.7^{\mathrm{a}}$ & $7.2^{\mathrm{b}}$ & $10.6^{\mathrm{a}}$ & $11.4^{\mathrm{a}}$ & $5.0^{\mathrm{b}}$ & 1.43 & $*$ & $*$ & NS \\
\hline Hay & $7.6^{\mathrm{b}}$ & $11.1^{\mathrm{b}}$ & $15.0^{\mathrm{ab}}$ & $12.7^{\mathrm{b}}$ & $22.2^{\mathrm{a}}$ & $12.8^{\mathrm{b}}$ & $13.0^{\mathrm{b}}$ & $15.2^{\mathrm{a}}$ & 1.00 & $*$ & * & NS \\
\hline Fresh herbage & $0.0^{\mathrm{b}}$ & $0.0^{\mathrm{b}}$ & $0.0^{\mathrm{b}}$ & $0.0^{\mathrm{b}}$ & $10.7^{\mathrm{a}}$ & 2.7 & 2.7 & 1.0 & 0.64 & $* * *$ & $\dagger$ & NS \\
\hline Ensiled ground ear corn & 4.9 & 5.1 & 2.0 & 10.6 & 0.0 & $4.3^{\mathrm{ab}}$ & $2.9 \mathrm{~b}$ & $6.3^{\mathrm{a}}$ & 0.93 & NS & $*$ & NS \\
\hline Commercial concentrate mix & $30.5^{\mathrm{a}}$ & $12.8^{\mathrm{b}}$ & $0.0^{\mathrm{c}}$ & $6.2 \mathrm{~b}^{\mathrm{c}}$ & $15.2^{\mathrm{b}}$ & 13.0 & 12.1 & 14.0 & 1.74 & $* *$ & NS & NS \\
\hline Soybean meal & $0.3^{\mathrm{c}}$ & $10.0^{\mathrm{a}}$ & $12.3^{\mathrm{a}}$ & $9.6^{\mathrm{a}}$ & $5.9^{\mathrm{b}}$ & 7.7 & 7.4 & 7.7 & 0.82 & $*$ & NS & NS \\
\hline Other starch-rich concentrates & 5.9 & 13.2 & 15.6 & 13.0 & 12.5 & $12.8^{\mathrm{ab}}$ & $14.0^{\mathrm{a}}$ & $9.4^{\mathrm{b}}$ & 1.14 & NS & * & NS \\
\hline Other protein-rich concentrates & $0.0^{\mathrm{b}}$ & $0.0^{\mathrm{b}}$ & $4.8^{\mathrm{a}}$ & $0.6^{\mathrm{b}}$ & $0.0^{\mathrm{b}}$ & 0.9 & 1.2 & 1.2 & 0.29 & $* * *$ & NS & NS \\
\hline Other concentrates & 1.4 & 8.2 & 4.2 & 2.7 & 1.9 & 3.6 & 3.6 & 3.8 & 0.56 & NS & NS & NS \\
\hline Oilseeds & 1.1 & 1.3 & 2.4 & 0.0 & 0.0 & 0.4 & 1.4 & 1.1 & 0.29 & NS & $\dagger$ & NS \\
\hline Fat & 0.0 & 0.0 & 0.5 & 0.3 & 0.0 & 0.2 & 0.2 & 0.1 & 0.05 & $\dagger$ & NS & NS \\
\hline Total roughage (with $60 \%$ corn silage) & $40.3^{\mathrm{bc}}$ & $36.7^{\mathrm{c}}$ & $41.8^{\mathrm{bc}}$ & $47.1^{\mathrm{b}}$ & $54.7^{\mathrm{a}}$ & 44.7 & 45.2 & 42.4 & 1.03 & $* * *$ & $\dagger$ & NS \\
\hline Total concentrates (with $40 \%$ corn silage) & $59.7^{\text {ab }}$ & $63.3^{\mathrm{a}}$ & $58.2^{\mathrm{ab}}$ & $52.9^{\mathrm{b}}$ & $45.3^{\mathrm{c}}$ & 55.3 & 54.8 & 57.6 & 1.03 & *** & NS & NS \\
\hline Total roughage (with full corn silage) & $55.9^{\mathrm{bc}}$ & $49.4^{\mathrm{c}}$ & $58.2^{\mathrm{b}}$ & $57.0^{\mathrm{b}}$ & $64.5^{\mathrm{a}}$ & 57.1 & 57.3 & 56.4 & 0.97 & $* *$ & NS & NS \\
\hline Total concentrate (without corn silage) & $44.1^{\mathrm{b}}$ & $50.6^{\mathrm{a}}$ & $41.8^{\mathrm{bc}}$ & $43.0^{\mathrm{b}}$ & $35.5^{\mathrm{c}}$ & 42.9 & 42.7 & 43.6 & 0.97 & ** & NS & NS \\
\hline Total grassland-derived conserved forage & $16.8^{\mathrm{b}}$ & $17.7^{\mathrm{b}}$ & $17.3^{\mathrm{b}}$ & $32.4^{\mathrm{a}}$ & $29.4^{\mathrm{a}}$ & 23.4 & 24.4 & 20.2 & 1.28 & ** & $t$ & NS \\
\hline
\end{tabular}

${ }^{\mathrm{a}-\mathrm{C}}$ Different superscript letters within the same row indicate differences among systems or periods $(P<0.05)$.

${ }^{1}$ Other starch-rich concentrates $=$ sum of corn and barley flour and flakes; other protein-rich concentrates $=$ sum of rapeseed and sunflower seed meals; other concentrates $=$ sum of brewers grain, distiller, rice husk, beet pulp, bran, and cane molasses; oilseeds = sum of linseeds, sunflower seeds, and cottonseeds; fat = sum of commercial mix of fat supplement based mainly on palm oil; total grassland-derived conserved forage $=$ sum of hay and grass or legume silage; total roughage $=$ sum of all the roughage source in cow diet.

${ }^{2} \mathrm{CCH}=$ farms feeding lactating cows with a high proportion of commercial concentrate mix; $\mathrm{CCM}=$ farms feeding lactating cows with a medium proportion of commercial con-

centrate mix; $\mathrm{CC} 0=$ farms feeding lactating cows without commercial concentrate mix; $\mathrm{HF}=$ farms feeding lactating cows with a high proportion of forages; $\mathrm{G}=$ farms feeding lactating cows with fresh herbage cut and fed indoors.

${ }^{3} \mathrm{P} 1=$ June to July; P2 = November to December; P3 = February to March.

$\quad * * * P<0.001 ; * * P<0.01 ; * P<0.05 ; \dagger P<0.1$ 
Table 2. Chemical composition of lactating herd diets according to feeding system and sampling period

\begin{tabular}{|c|c|c|c|c|c|c|c|c|c|c|c|c|}
\hline \multirow[b]{2}{*}{ Item } & \multicolumn{5}{|c|}{ System $^{1}$} & \multicolumn{3}{|c|}{ Period $^{2}$} & \multirow[b]{2}{*}{ SEM } & \multicolumn{3}{|c|}{ Effect and significance } \\
\hline & $\mathrm{CCH}$ & $\mathrm{CCM}$ & $\mathrm{CC} 0$ & $\mathrm{HF}$ & $\mathrm{G}$ & $\mathrm{P} 1$ & $\mathrm{P} 2$ & P3 & & System & Period & Interaction \\
\hline $\mathrm{DM}(\%)$ & 51.90 & 54.44 & 52.68 & 52.13 & 51.74 & 51.59 & 52.55 & 53.58 & 0.577 & NS & NS & NS \\
\hline Ash (\% of DM) & 7.47 & 7.82 & 7.03 & 7.60 & 7.87 & $7.63^{\mathrm{a}}$ & $7.99^{\mathrm{a}}$ & $7.05^{\mathrm{b}}$ & 0.121 & NS & $*$ & NS \\
\hline $\mathrm{NDF}(\%$ of DM) & $35.37^{\mathrm{b}}$ & $33.62^{\mathrm{b}}$ & $34.17^{\mathrm{b}}$ & $36.34^{\mathrm{b}}$ & $40.35^{\mathrm{a}}$ & 36.38 & 36.11 & 35.43 & 0.426 & $* * *$ & NS & NS \\
\hline $\mathrm{CP}(\%$ of $\mathrm{DM})$ & 15.42 & 16.69 & 15.81 & 15.12 & 14.99 & 15.45 & 15.95 & 15.41 & 0.16 & NS & $t$ & NS \\
\hline $\mathrm{EE}^{3}(\%$ of $\mathrm{DM})$ & 3.07 & 3.77 & 3.60 & 3.39 & 2.95 & $3.11^{\mathrm{b}}$ & $3.33^{\text {ab }}$ & $3.33^{\mathrm{a}}$ & 0.083 & $t$ & $* *$ & NS \\
\hline Starch (\% of DM) & $26.49^{\mathrm{a}}$ & $24.85^{\text {ab }}$ & $27.05^{\mathrm{a}}$ & $24.45^{\text {ab }}$ & $21.84^{\mathrm{b}}$ & 24.93 & 24.86 & 24.86 & 0.410 & $* *$ & NS & NS \\
\hline NSC ( $\%$ of DM) & $40.34^{\mathrm{a}}$ & $39.32^{\mathrm{ab}}$ & $40.56^{\mathrm{a}}$ & $39.08^{\mathrm{ab}}$ & $34.40^{\mathrm{b}}$ & 38.51 & 38.13 & 38.13 & 0.479 & $*$ & NS & NS \\
\hline
\end{tabular}

${ }^{\mathrm{a}, \mathrm{b}}$ Different superscript letters within the same row indicate differences among systems or periods $(P<0.05)$.

${ }^{1} \mathrm{CCH}=$ farms feeding lactating cows with a high proportion of commercial concentrate mix; CCM = farms feeding lactating cows with a medium proportion of commercial concentrate mix; $\mathrm{CC} 0=$ farms feeding lactating cows without commercial concentrate mix; HF = farms feeding lactating cows with a high proportion of forages; $\mathrm{G}=$ farms feeding lactating cows with fresh herbage cut and fed indoors.

${ }^{2} \mathrm{P} 1$ = June to July; P2 = November to December; P3 = February to March.

${ }^{3} \mathrm{EE}=$ ether extract.

${ }^{* * *} P<0.001 ; * * P<0.01 ; * P<0.05 ; \dagger P<0.1$

Table 3. Lactating herd performance and characteristics according to feeding system and sampling period

\begin{tabular}{|c|c|c|c|c|c|c|c|c|c|c|c|c|}
\hline \multirow[b]{2}{*}{ Item } & \multicolumn{5}{|c|}{ System $^{1}$} & \multicolumn{3}{|c|}{ Period $^{2}$} & \multirow[b]{2}{*}{ SEM } & \multicolumn{3}{|c|}{ Effect and significance } \\
\hline & $\mathrm{CCH}$ & $\mathrm{CCM}$ & $\mathrm{CC} 0$ & $\mathrm{HF}$ & $\mathrm{G}$ & $\mathrm{P} 1$ & $\mathrm{P} 2$ & P3 & & System & Period & Interaction \\
\hline Dairy cows (no.) & $190^{\mathrm{a}}$ & $172^{\mathrm{a}}$ & $175^{\mathrm{a}}$ & $80^{\mathrm{b}}$ & $80^{\mathrm{b}}$ & 138 & 140 & 141 & 10.9 & * & NS & NS \\
\hline Milk yield $(\mathrm{L} /$ cow $\times \mathrm{d})$ & $30.4^{\mathrm{ab}}$ & $32.7^{\mathrm{a}}$ & $29.9^{\mathrm{ab}}$ & $28.0^{\mathrm{bc}}$ & $25.7^{\mathrm{c}}$ & $\begin{aligned} 100 \\
29.2^{\mathrm{ab}}\end{aligned}$ & $\begin{array}{r}140 \\
28.8^{\mathrm{b}}\end{array}$ & $30.1^{\mathrm{a}}$ & $\begin{array}{r}10.9 \\
0.51\end{array}$ & $*$ & $*$ & NS \\
\hline $3.5 \%$ FCM $(\mathrm{L} /$ cow $\times \mathrm{d})$ & $33.0^{\mathrm{b}}$ & $33.2^{\mathrm{b}}$ & $31.1^{\mathrm{ab}}$ & $29.8^{\mathrm{ab}}$ & $27.5^{\mathrm{b}}$ & 30.0 & $\begin{array}{l}20.0 \\
30.6\end{array}$ & 32.1 & 0.53 & $*$ & $\dagger$ & NS \\
\hline DIM & 186 & 204 & 202 & 195 & 201 & $213^{\mathrm{a}}$ & $190^{\mathrm{b}}$ & $190^{\mathrm{b}}$ & 3.6 & NS & $* * *$ & NS \\
\hline Fat $(\mathrm{g} / 100 \mathrm{~g}$ of milk $)$ & $4.01^{\mathrm{a}}$ & $3.59^{\mathrm{c}}$ & $3.74^{\mathrm{bc}}$ & $3.86^{\mathrm{ab}}$ & $395^{\mathrm{a}}$ & $368^{\mathrm{b}}$ & $3.88^{\mathrm{a}}$ & $393^{\mathrm{a}}$ & 0.035 & $*$ & $* * *$ & NS \\
\hline Protein (g/100 g of milk) & 3.45 & 3.31 & 3.37 & 3.35 & 3.36 & $3.28^{\mathrm{b}}$ & $3.42^{\mathrm{a}}$ & $3.40^{\mathrm{a}}$ & 0.018 & NS & ** & NS \\
\hline Lactose ( $\mathrm{g} / 100 \mathrm{~g}$ of milk) & 4.86 & 4.89 & 4.81 & 4.80 & 4.81 & $4.85^{\mathrm{a}}$ & $4.81^{\mathrm{b}}$ & $4.84^{\mathrm{a}}$ & 0.011 & NS & $*$ & NS \\
\hline Caseins (g/100 g of milk) & 2.71 & 2.60 & 2.64 & 2.62 & 2.64 & $2.55^{\mathrm{b}}$ & $2.69^{\mathrm{a}}$ & $2.69^{\mathrm{a}}$ & 0.015 & NS & $* * *$ & NS \\
\hline Urea (mg/dL of milk) & 19.7 & 22.0 & 20.8 & 19.7 & 18.3 & 20.6 & 18.9 & 20.8 & 0.56 & NS & NS & NS \\
\hline $\mathrm{SCC}(\times 1.000 / \mathrm{mL}$ of milk $)$ & 284 & 220 & 220 & 284 & 232 & 258 & 247 & 239 & 11.6 & NS & NS & NS \\
\hline $\mathrm{TBC}^{3}(\mathrm{cfu} \times 1.000 / \mathrm{mL}$ of milk $)$ & $\begin{array}{r}284 \\
17\end{array}$ & 15 & 24 & 15 & $\begin{array}{r}202 \\
15\end{array}$ & $\begin{array}{r}200 \\
23\end{array}$ & $\begin{array}{r}241 \\
15\end{array}$ & 14 & 2.0 & NS & NS & NS \\
\hline
\end{tabular}

${ }^{\mathrm{a}-\mathrm{c}}$ Different superscript letters within the same row indicate differences among systems or periods $(P<0.05)$.

${ }^{1} \mathrm{CCH}=$ farms feeding lactating cows with a high proportion of commercial concentrate mix; CCM = farms feeding lactating cows with a medium proportion of commercial concentrate mix; $\mathrm{CC} 0=$ farms feeding lactating cows without commercial concentrate mix; $\mathrm{HF}=$ farms feeding lactating cows with a high proportion of forages; $\mathrm{G}=$ farms feeding lactating cows with fresh herbage cut and fed indoors.

${ }^{2} \mathrm{P} 1$ = June to July; P2 = November to December; P3 = February to March

${ }^{3} \mathrm{TBC}=$ total bacteria count.

$* * * P<0.001 ; * * P<0.01 ; * P<0.05 ; \dagger P<0.1$. 
Table 4. Milk FA composition according to feeding system and sampling period

\begin{tabular}{|c|c|c|c|c|c|c|c|c|c|c|c|c|}
\hline \multirow[b]{2}{*}{$\mathrm{FA}(\mathrm{g} / 100 \mathrm{~g}$ of $\mathrm{FA})$} & \multicolumn{5}{|c|}{ System $^{1}$} & \multicolumn{3}{|c|}{ Period $^{2}$} & \multirow[b]{2}{*}{ SEM } & \multicolumn{3}{|c|}{ Effect and significance } \\
\hline & $\mathrm{CCH}$ & $\mathrm{CCM}$ & $\mathrm{CC} 0$ & $\mathrm{HF}$ & G & $\mathrm{P} 1$ & $\mathrm{P} 2$ & P3 & & System & Period & Interaction \\
\hline $\mathrm{C} 4: 0$ & $3.14^{\mathrm{ab}}$ & $3.08^{\mathrm{b}}$ & $3.08^{\mathrm{b}}$ & $3.11^{\mathrm{ab}}$ & $3.28^{\mathrm{a}}$ & $3.22^{\mathrm{a}}$ & $3.10^{\mathrm{b}}$ & $3.10^{\mathrm{b}}$ & 0.023 & * & $* *$ & NS \\
\hline C5:0 & $0.041^{\mathrm{a}}$ & $0.038^{\mathrm{a}}$ & $0.040^{\mathrm{a}}$ & $0.036^{\mathrm{ab}}$ & $0.029^{\mathrm{b}}$ & $0.034^{\mathrm{b}}$ & $0.038^{\mathrm{ab}}$ & $0.039^{\mathrm{a}}$ & 0.001 & $*$ & * & NS \\
\hline C6:0 & $2.27^{\mathrm{ab}}$ & $2.12^{\mathrm{c}}$ & $2.14^{\mathrm{bc}}$ & $2.25^{\mathrm{ab}}$ & $2.34^{\mathrm{a}}$ & 2.23 & 2.20 & 2.24 & 0.017 & $* * *$ & NS & NS \\
\hline C7:0 & $0.038^{\mathrm{a}}$ & $0.035^{\mathrm{ab}}$ & $0.039^{\mathrm{a}}$ & $0.033^{\mathrm{ab}}$ & $0.028^{\mathrm{b}}$ & 0.031 & 0.035 & 0.037 & 0.001 & $*$ & $\dagger$ & NS \\
\hline C8:0 & $1.31^{\mathrm{a}}$ & $1.20^{\mathrm{b}}$ & $1.22^{\mathrm{ab}}$ & $1.30^{\mathrm{a}}$ & $1.32^{\mathrm{a}}$ & 1.25 & 1.25 & 1.30 & 0.012 & $*$ & $t$ & NS \\
\hline C9:0 & $0.048^{\mathrm{a}}$ & $0.042^{\mathrm{ab}}$ & $0.045^{\mathrm{ab}}$ & $0.041^{\mathrm{ab}}$ & $0.034^{\mathrm{b}}$ & $0.036^{\mathrm{b}}$ & $0.043^{\mathrm{ab}}$ & $0.047^{\mathrm{a}}$ & 0.002 & $*$ & $* *$ & NS \\
\hline C10:0 & $3.01^{\mathrm{a}}$ & $2.68^{\mathrm{b}}$ & $2.73^{\mathrm{b}}$ & $2.91^{\mathrm{a}}$ & $2.97^{\mathrm{a}}$ & $2.78^{\mathrm{b}}$ & $2.83^{\mathrm{ab}}$ & $2.97^{\mathrm{a}}$ & 0.036 & $*$ & $* *$ & NS \\
\hline cis-9 C10:1 & $0.30^{\mathrm{a}}$ & $0.25^{\mathrm{b}}$ & $0.26^{\mathrm{b}}$ & $0.30^{\mathrm{a}}$ & $0.30^{\mathrm{a}}$ & 0.27 & 0.29 & 0.28 & 0.005 & * & $\dagger$ & NS \\
\hline C11:0 & 0.08 & 0.07 & 0.07 & 0.07 & 0.06 & $0.06^{\mathrm{b}}$ & $0.07^{\mathrm{ab}}$ & $0.08^{\mathrm{a}}$ & 0.003 & $\dagger$ & $*$ & NS \\
\hline C12:0 & $3.46^{\mathrm{a}}$ & $3.02^{\mathrm{b}}$ & $3.11^{\mathrm{ab}}$ & $3.33^{\mathrm{a}}$ & $3.37^{\mathrm{a}}$ & $3.13^{\mathrm{b}}$ & $3.23^{\mathrm{ab}}$ & $3.41^{\mathrm{a}}$ & 0.047 & $*$ & $*$ & NS \\
\hline iso $\mathrm{C} 13: 0$ & $0.029^{\mathrm{ab}}$ & $0.025^{\mathrm{b}}$ & $0.028^{\mathrm{b}}$ & $0.026^{\mathrm{b}}$ & $0.034^{\mathrm{a}}$ & $0.029^{\mathrm{a}}$ & $0.029^{\mathrm{a}}$ & $0.026^{\mathrm{b}}$ & 0.001 & ** & $* * *$ & NS \\
\hline anteiso $\mathrm{C} 13: 0$ & $0.010^{\mathrm{ab}}$ & $0.008^{\mathrm{b}}$ & $0.011^{\mathrm{ab}}$ & $0.010^{\mathrm{ab}}$ & $0.013^{\mathrm{a}}$ & $0.011^{\mathrm{a}}$ & $0.011^{\mathrm{a}}$ & $0.009^{\mathrm{b}}$ & 0.000 & $* *$ & $* * *$ & NS \\
\hline cis-9 C12:1 & $0.097^{\mathrm{a}}$ & $0.079^{\mathrm{b}}$ & $0.084^{\mathrm{ab}}$ & $0.092^{\mathrm{a}}$ & $0.092^{\mathrm{a}}$ & $0.082^{\mathrm{b}}$ & $0.092^{\mathrm{a}}$ & $0.093^{\mathrm{a}}$ & 0.002 & $*$ & $*$ & NS \\
\hline C13:0 & 0.13 & 0.12 & 0.12 & 0.11 & 0.10 & $0.11^{\mathrm{b}}$ & $0.12^{\mathrm{ab}}$ & $0.13^{\mathrm{a}}$ & 0.003 & NS & * & NS \\
\hline iso C14:0 & $0.09^{\mathrm{b}}$ & $0.07^{\mathrm{c}}$ & $0.09^{\mathrm{b}}$ & $0.08^{\mathrm{bc}}$ & $0.12^{\mathrm{a}}$ & 0.09 & 0.09 & 0.09 & 0.003 & $*$ & NS & NS \\
\hline C14:0 & $10.68^{\mathrm{ab}}$ & $9.95^{\mathrm{c}}$ & $10.24^{\mathrm{bc}}$ & $10.60^{\mathrm{ab}}$ & $11.13^{\mathrm{a}}$ & $10.35^{\mathrm{b}}$ & $10.53^{\mathrm{ab}}$ & $10.69^{\mathrm{a}}$ & 0.084 & ** & $*$ & NS \\
\hline iso C15:0 & $0.20^{\mathrm{b}}$ & $0.18^{\mathrm{b}}$ & $0.19^{\mathrm{b}}$ & $0.19^{\mathrm{b}}$ & $0.23^{\mathrm{a}}$ & $0.205^{\mathrm{a}}$ & $0.195^{\mathrm{b}}$ & $0.198^{\mathrm{b}}$ & 0.003 & $*$ & $*$ & NS \\
\hline trans-9 C14:1 & 0.01 & 0.01 & 0.02 & 0.01 & 0.01 & 0.01 & 0.02 & 0.01 & 0.000 & NS & $\dagger$ & NS \\
\hline anteiso $\mathrm{C} 15: 0$ & $0.43^{\mathrm{ab}}$ & $0.39^{\mathrm{b}}$ & $0.43^{\mathrm{ab}}$ & $0.43^{\mathrm{ab}}$ & $0.48^{\mathrm{a}}$ & $0.44^{\mathrm{a}}$ & $0.43^{\mathrm{ab}}$ & $0.42^{\mathrm{b}}$ & 0.006 & $*$ & * & NS \\
\hline cis-9 C14:1 & 1.02 & 0.93 & 0.97 & 1.01 & 1.02 & $0.93^{\mathrm{b}}$ & $1.05^{\mathrm{a}}$ & $0.99^{\mathrm{ab}}$ & 0.015 & NS & $* *$ & NS \\
\hline C15:0 & 1.13 & 1.04 & 1.11 & 1.08 & 1.09 & 1.06 & 1.10 & 1.11 & 0.016 & NS & NS & NS \\
\hline iso C16:0 & 0.20 & 0.19 & 0.21 & 0.20 & 0.24 & $0.22^{\mathrm{a}}$ & $0.20^{\mathrm{b}}$ & $0.20^{\mathrm{b}}$ & 0.005 & NS & $*$ & NS \\
\hline C16:0 & $31.53^{\mathrm{a}}$ & $27.86^{\mathrm{c}}$ & $29.14^{\mathrm{bc}}$ & $30.17^{\mathrm{ab}}$ & $31.23^{\mathrm{a}}$ & 29.44 & 30.50 & 30.02 & 0.263 & $* *$ & $\dagger$ & NS \\
\hline iso C17:0 & 0.28 & 0.30 & 0.28 & 0.30 & 0.28 & 0.30 & 0.28 & 0.28 & 0.004 & NS & NS & NS \\
\hline trans-11 C16:1 & 0.17 & 0.19 & 0.16 & 0.17 & 0.17 & 0.18 & 0.18 & 0.16 & 0.004 & NS & NS & NS \\
\hline cis-9 C16:1 & 1.86 & 1.75 & 1.77 & 1.82 & 1.78 & $1.72^{\mathrm{b}}$ & $1.84^{\mathrm{a}}$ & $1.83^{\mathrm{a}}$ & 0.024 & NS & $* *$ & NS \\
\hline anteiso C17:0 & 0.14 & 0.14 & 0.14 & 0.14 & 0.14 & 0.14 & 0.14 & 0.13 & 0.002 & NS & NS & NS \\
\hline cis-11 C16:1 & $0.024^{\mathrm{b}}$ & $0.027^{\mathrm{a}}$ & $0.025^{\mathrm{ab}}$ & $0.02^{\mathrm{b}}$ & $0.029^{\mathrm{a}}$ & 0.02 & 0.03 & 0.03 & 0.001 & $*$ & NS & NS \\
\hline C17:0 & 0.50 & 0.50 & 0.51 & 0.51 & 0.53 & 0.52 & 0.50 & 0.51 & 0.005 & NS & NS & NS \\
\hline iso C18:0 & 0.05 & 0.05 & 0.05 & 0.05 & 0.06 & 0.048 & 0.049 & 0.051 & 0.001 & NS & NS & NS \\
\hline cis-9 C17:1 & 0.22 & 0.23 & 0.22 & 0.23 & 0.23 & 0.22 & 0.23 & 0.22 & 0.004 & NS & NS & NS \\
\hline C18:0 & 8.81 & 9.91 & 9.43 & 9.02 & 9.10 & $9.84^{\mathrm{a}}$ & $8.90^{\mathrm{b}}$ & $9.03^{\mathrm{ab}}$ & 0.153 & NS & $* *$ & NS \\
\hline trans-4 C18:1 & $0.020^{\mathrm{b}}$ & $0.027^{\mathrm{a}}$ & $0.027^{\mathrm{a}}$ & $0.019^{\mathrm{b}}$ & $0.016^{\mathrm{b}}$ & 0.021 & 0.023 & 0.021 & 0.001 & * & NS & NS \\
\hline trans $-5 \mathrm{C} 18: 1$ & 0.02 & 0.02 & 0.02 & 0.02 & 0.02 & $0.019^{\mathrm{ab}}$ & $0.022^{\mathrm{a}}$ & $0.017^{\mathrm{b}}$ & 0.001 & $\dagger$ & $* *$ & NS \\
\hline trans- $6 / 7 / 8 \mathrm{C} 18: 1$ & $0.26^{\mathrm{bc}}$ & $0.35^{\mathrm{a}}$ & $0.33^{\mathrm{ab}}$ & $0.27^{\mathrm{bc}}$ & $0.23^{\mathrm{c}}$ & $0.29^{\mathrm{ab}}$ & $0.27^{\mathrm{b}}$ & $0.31^{\mathrm{a}}$ & 0.008 & $* *$ & $* *$ & NS \\
\hline trans-9 C18:1 & $0.20^{\mathrm{b}}$ & $0.27^{\mathrm{a}}$ & $0.27^{\mathrm{a}}$ & $0.21^{\mathrm{b}}$ & $0.18^{\mathrm{b}}$ & 0.22 & 0.22 & 0.22 & 0.006 & $* * *$ & NS & NS \\
\hline trans-10 C18:1 & $0.40^{\mathrm{b}}$ & $0.69^{\mathrm{a}}$ & $0.56^{\mathrm{ab}}$ & $0.45^{\mathrm{b}}$ & $0.28^{\mathrm{c}}$ & 0.46 & 0.44 & 0.53 & 0.027 & $* *$ & $t$ & NS \\
\hline trans-11 C18:1 & $0.74^{\mathrm{c}}$ & $1.07^{\mathrm{a}}$ & $0.96^{\mathrm{ab}}$ & $0.88^{\mathrm{bc}}$ & $0.90^{\mathrm{bc}}$ & 0.96 & 0.86 & 0.91 & 0.025 & ** & $t$ & NS \\
\hline trans-12 + cis-6 C18:1 & $0.33^{\mathrm{b}}$ & $0.52^{\mathrm{a}}$ & $0.45^{\mathrm{a}}$ & $0.36^{\mathrm{b}}$ & $0.28^{\mathrm{b}}$ & $0.37^{\mathrm{b}}$ & $0.36^{\mathrm{b}}$ & $0.43^{\mathrm{a}}$ & 0.015 & $* * *$ & ** & NS \\
\hline trans-13 C18:1 & $0.42^{\mathrm{ab}}$ & $0.55^{\mathrm{a}}$ & $0.52^{\mathrm{ab}}$ & $0.41^{\mathrm{ab}}$ & $0.35^{\mathrm{b}}$ & $0.47^{\mathrm{a}}$ & $0.49^{\mathrm{a}}$ & $0.38^{\mathrm{b}}$ & 0.016 & $*$ & $* * *$ & NS \\
\hline cis-9 C18:1 & $18.44^{\mathrm{b}}$ & $20.94^{\mathrm{a}}$ & $20.13^{\mathrm{a}}$ & $19.45^{\mathrm{ab}}$ & $18.52^{\mathrm{b}}$ & 19.80 & 19.42 & 19.27 & 0.193 & ** & NS & NS \\
\hline cis-10 C18:1 & $0.44^{\mathrm{c}}$ & $0.57^{\mathrm{a}}$ & $0.54^{\mathrm{ab}}$ & $0.49^{\mathrm{ab}}$ & $0.43^{\mathrm{c}}$ & $0.45^{\mathrm{b}}$ & $0.58^{\mathrm{a}}$ & $0.45^{\mathrm{b}}$ & 0.014 & $*$ & $* * *$ & NS \\
\hline cis-11 C18:1 & $0.67^{\mathrm{ab}}$ & $0.81^{\mathrm{a}}$ & $0.79^{\mathrm{a}}$ & $0.68^{\mathrm{ab}}$ & $0.57^{\mathrm{b}}$ & 0.68 & 0.72 & 0.72 & 0.018 & * & NS & NS \\
\hline cis-12 C18:1 & $0.36^{\mathrm{bc}}$ & $0.53^{\mathrm{a}}$ & $0.46^{\mathrm{ab}}$ & $0.37^{\mathrm{bc}}$ & $0.29^{\mathrm{c}}$ & 0.39 & 0.38 & 0.43 & 0.016 & ** & $\dagger$ & NS \\
\hline cis-13 C18:1 & $0.08^{\mathrm{ab}}$ & $0.10^{\mathrm{a}}$ & $0.09^{\mathrm{a}}$ & $0.08^{\mathrm{ab}}$ & $0.07^{\mathrm{b}}$ & 0.09 & 0.08 & 0.09 & 0.003 & $*$ & $\dagger$ & NS \\
\hline trans- $16+$ cis-14 C18:1 & $0.25^{\mathrm{b}}$ & $0.37^{\mathrm{a}}$ & $0.31^{\mathrm{ab}}$ & $0.28^{\mathrm{ab}}$ & $0.25^{\mathrm{b}}$ & $0.29^{\mathrm{ab}}$ & $0.27^{\mathrm{b}}$ & $0.31^{\mathrm{a}}$ & 0.009 & $* *$ & $*$ & NS \\
\hline cis-15 C18:1 & 0.04 & 0.07 & 0.05 & 0.04 & 0.04 & $0.04^{\mathrm{b}}$ & $0.04^{\mathrm{b}}$ & $0.06^{\mathrm{a}}$ & 0.004 & NS & * & NS \\
\hline C19:0 & 0.04 & 0.04 & 0.04 & 0.03 & 0.03 & $0.03^{\mathrm{b}}$ & $0.04^{\mathrm{a}}$ & $0.03^{\mathrm{b}}$ & 0.001 & $\dagger$ & * & NS \\
\hline cis-9,trans-13 C18:2 & $0.19^{\mathrm{bc}}$ & $0.28^{\mathrm{a}}$ & $0.23^{\mathrm{ab}}$ & $0.19^{\mathrm{bc}}$ & $0.16^{\mathrm{c}}$ & $0.20^{\mathrm{b}}$ & $0.21^{\mathrm{ab}}$ & $0.22^{\mathrm{a}}$ & 0.007 & $* * *$ & $*$ & NS \\
\hline cis-9,trans- $12+$ cis-9,trans-14 C18:2 & $0.08^{\mathrm{bc}}$ & $0.11^{\mathrm{a}}$ & $0.09^{\mathrm{ab}}$ & $0.08^{\mathrm{bc}}$ & $0.07^{\mathrm{c}}$ & $0.08^{\mathrm{b}}$ & $0.09^{\mathrm{ab}}$ & $0.10^{\mathrm{a}}$ & 0.003 & $* *$ & $* *$ & NS \\
\hline & & & & & & & & & & & & Continued \\
\hline
\end{tabular}




\begin{tabular}{|c|c|c|c|c|c|c|c|c|c|c|c|c|}
\hline \multirow[b]{2}{*}{ FA $(\mathrm{g} / 100 \mathrm{~g}$ of $\mathrm{FA})$} & \multicolumn{5}{|c|}{ System $^{1}$} & \multicolumn{3}{|c|}{ Period $^{2}$} & \multirow[b]{2}{*}{ SEM } & \multicolumn{3}{|c|}{ Effect and significance } \\
\hline & $\mathrm{CCH}$ & CCM & $\mathrm{CC} 0$ & $\mathrm{HF}$ & $\mathrm{G}$ & $\mathrm{P} 1$ & $\mathrm{P} 2$ & P3 & & System & Period & Interaction \\
\hline cis-16 C18:1 & $0.04^{\mathrm{ab}}$ & $0.04^{\mathrm{a}}$ & $0.04^{\mathrm{ab}}$ & $0.03^{\mathrm{b}}$ & $0.03^{\mathrm{b}}$ & $0.03^{\mathrm{b}}$ & $0.04^{\mathrm{a}}$ & $0.04^{\mathrm{a}}$ & 0.001 & ** & $*$ & NS \\
\hline trans-11,cis-15 C18:2 & 0.05 & 0.08 & 0.06 & 0.07 & 0.09 & 0.08 & 0.07 & 0.07 & 0.003 & $\dagger$ & NS & NS \\
\hline $\mathrm{C} 18: 2 \mathrm{n}-6$ & $2.29^{\mathrm{ab}}$ & $2.70^{\mathrm{a}}$ & $2.57^{\mathrm{a}}$ & $2.48^{\mathrm{a}}$ & $1.87^{\mathrm{b}}$ & 2.41 & 2.27 & 2.47 & 0.064 & $*$ & NS & NS \\
\hline cis-10 C19:1 & 0.05 & 0.06 & 0.05 & 0.04 & 0.05 & $0.04^{\mathrm{b}}$ & $0.06^{\mathrm{a}}$ & $0.05^{\mathrm{ab}}$ & 0.003 & NS & $* *$ & NS \\
\hline $\mathrm{C} 20: 0$ & 0.10 & 0.11 & 0.11 & 0.12 & 0.13 & $0.13^{\mathrm{a}}$ & $0.11^{\mathrm{b}}$ & $0.11^{\mathrm{b}}$ & 0.003 & $\dagger$ & $* *$ & NS \\
\hline C18:3n-6 & 0.038 & 0.036 & 0.040 & 0.034 & 0.036 & $0.037^{\mathrm{ab}}$ & $0.040^{\mathrm{a}}$ & $0.034^{\mathrm{b}}$ & 0.001 & NS & * & NS \\
\hline C18:3n-3 & $0.37^{\mathrm{c}}$ & $0.51^{\mathrm{ab}}$ & $0.45^{\mathrm{b}}$ & $0.57^{\mathrm{a}}$ & $0.48^{\mathrm{b}}$ & $0.51^{\mathrm{a}}$ & $0.45^{\mathrm{b}}$ & $0.46^{\mathrm{b}}$ & 0.013 & $*$ & $*$ & NS \\
\hline cis-11 C20:1 & 0.04 & 0.05 & 0.05 & 0.04 & 0.04 & $0.04^{\mathrm{b}}$ & $0.05^{\mathrm{a}}$ & $0.04^{\mathrm{b}}$ & 0.002 & $\dagger$ & $* *$ & NS \\
\hline cis-9,trans-11 CLA & $0.37^{\mathrm{c}}$ & $0.53^{\mathrm{a}}$ & $0.48^{\mathrm{ab}}$ & $0.44^{\mathrm{b}}$ & $0.42^{\mathrm{bc}}$ & 0.45 & 0.43 & 0.46 & 0.011 & $*$ & NS & NS \\
\hline $\mathrm{C} 21: 0$ & 0.01 & 0.01 & 0.01 & 0.01 & 0.02 & 0.01 & 0.02 & 0.01 & 0.001 & NS & NS & NS \\
\hline cis-9,cis-11 CLA & $0.025^{\mathrm{ab}}$ & $0.022^{\mathrm{b}}$ & $0.024^{\mathrm{ab}}$ & $0.022^{\mathrm{b}}$ & $0.031^{\mathrm{a}}$ & $0.024^{\mathrm{b}}$ & $0.033^{\mathrm{a}}$ & $0.016^{\mathrm{b}}$ & 0.001 & $*$ & $* * *$ & NS \\
\hline trans-11,trans-13 CLA & 0.031 & 0.036 & 0.034 & 0.027 & 0.027 & $0.028^{\mathrm{b}}$ & $0.037^{\mathrm{a}}$ & $0.028^{\mathrm{b}}$ & 0.002 & NS & $*$ & NS \\
\hline trans-9,trans-11 CLA & 0.021 & 0.023 & 0.023 & 0.011 & 0.019 & $0.015^{\mathrm{b}}$ & $0.028^{\mathrm{a}}$ & $0.015^{\mathrm{b}}$ & 0.002 & $t$ & $* * *$ & NS \\
\hline $\mathrm{C} 20: 2 \mathrm{n}-6$ & 0.033 & 0.033 & 0.035 & 0.033 & 0.030 & $0.033^{\mathrm{ab}}$ & $0.041^{\mathrm{a}}$ & $0.025^{\mathrm{b}}$ & 0.002 & NS & $* * *$ & NS \\
\hline $\mathrm{C} 22: 0$ & $0.10^{\mathrm{ab}}$ & $0.11^{\mathrm{a}}$ & $0.12^{\mathrm{a}}$ & $0.10^{\mathrm{ab}}$ & $0.09^{\mathrm{b}}$ & 0.10 & 0.11 & 0.10 & 0.002 & ** & NS & NS \\
\hline C20:3n-6 & 0.036 & 0.038 & 0.044 & 0.04 & 0.053 & $0.044^{\mathrm{ab}}$ & $0.051^{\mathrm{a}}$ & $0.033^{\mathrm{b}}$ & 0.002 & $\dagger$ & $* * *$ & NS \\
\hline C20:4n-6 & 0.18 & 0.17 & 0.18 & 0.16 & 0.15 & 0.16 & 0.16 & 0.17 & 0.003 & $\dagger$ & NS & NS \\
\hline $\mathrm{C} 23: 0$ & 0.12 & 0.10 & 0.12 & 0.07 & 0.10 & $0.08^{\mathrm{b}}$ & $0.16^{\mathrm{a}}$ & $0.06^{\mathrm{b}}$ & 0.008 & NS & $* * *$ & NS \\
\hline C20:5n-3 & $0.030^{\mathrm{b}}$ & $0.039^{\mathrm{ab}}$ & $0.038^{\mathrm{ab}}$ & $0.042^{\mathrm{a}}$ & $0.044^{\mathrm{a}}$ & $0.039^{\mathrm{a}}$ & $0.042^{\mathrm{a}}$ & $0.034^{\mathrm{b}}$ & 0.001 & $* *$ & $*$ & NS \\
\hline $\mathrm{C} 24: 0$ & 0.023 & 0.019 & 0.023 & 0.024 & 0.025 & $0.026^{\mathrm{a}}$ & $0.026^{\mathrm{a}}$ & $0.016^{\mathrm{b}}$ & 0.001 & NS & $* * *$ & NS \\
\hline $\mathrm{C} 22: 3 \mathrm{n}-3+$ cis-9 C24:1 & 0.04 & 0.03 & 0.04 & 0.03 & 0.03 & 0.04 & 0.03 & 0.03 & 0.001 & $\dagger$ & NS & NS \\
\hline $\mathrm{C} 22: 4 n-6$ & 0.01 & 0.01 & 0.01 & 0.01 & 0.01 & 0.008 & 0.009 & 0.007 & 0.001 & NS & NS & NS \\
\hline $\mathrm{C} 22: 5 \mathrm{n}-3$ & $0.059^{b}$ & $0.062^{\mathrm{b}}$ & $0.063^{\mathrm{b}}$ & $0.075^{\mathrm{a}}$ & $0.069^{\mathrm{ab}}$ & $0.071^{\mathrm{a}}$ & $0.062^{\mathrm{b}}$ & $0.064^{\mathrm{b}}$ & 0.001 & $*$ & $* *$ & NS \\
\hline $\mathrm{C} 22: 6 \mathrm{n}-3$ & 0.030 & 0.030 & 0.026 & 0.030 & 0.037 & $0.039^{\mathrm{a}}$ & $0.031^{\mathrm{ab}}$ & $0.022^{\mathrm{b}}$ & 0.002 & NS & $* *$ & NS \\
\hline SFA & $67.84^{\mathrm{a}}$ & $63.10^{\mathrm{b}}$ & $64.69^{\mathrm{b}}$ & $66.22^{\mathrm{ab}}$ & $68.45^{\mathrm{a}}$ & 65.83 & 66.11 & 66.23 & 0.341 & $* *$ & NS & NS \\
\hline MUFA & $26.79^{\mathrm{c}}$ & $30.77^{\mathrm{a}}$ & $29.45^{\mathrm{ab}}$ & $28.09^{\mathrm{bc}}$ & $25.80^{\mathrm{c}}$ & 28.40 & 28.32 & 28.21 & 0.279 & $* *$ & NS & NS \\
\hline PUFA & $4.18^{\mathrm{ab}}$ & $5.03^{\mathrm{a}}$ & $4.72^{\mathrm{a}}$ & $4.61^{\mathrm{a}}$ & $3.88^{\mathrm{b}}$ & 4.56 & 4.38 & 4.51 & 0.086 & * & NS & NS \\
\hline$\Sigma$ trans $\mathrm{FA}$ & $3.52^{\mathrm{bc}}$ & $5.01^{\mathrm{a}}$ & $4.46^{\mathrm{ab}}$ & $3.83^{\text {bc }}$ & $3.40^{\mathrm{c}}$ & 4.09 & 3.94 & 4.10 & 0.105 & ** & NS & NS \\
\hline$\Sigma$ trans $\mathrm{C} 18: 1$ & $2.38^{\mathrm{bc}}$ & $3.50^{\mathrm{a}}$ & $3.13^{\mathrm{ab}}$ & $2.62^{\mathrm{bc}}$ & $2.25^{\mathrm{c}}$ & 2.81 & 2.68 & 2.83 & 0.083 & $* *$ & NS & NS \\
\hline$\Sigma$ cis $\mathrm{C} 18: 1$ & $20.33^{\mathrm{b}}$ & $23.43^{\mathrm{a}}$ & $22.41^{\mathrm{a}}$ & $21.42^{\mathrm{ab}}$ & $20.18^{\mathrm{b}}$ & 21.77 & 21.52 & 21.37 & 0.228 & ** & NS & NS \\
\hline De novo synthesis of FA & $23.88^{\mathrm{ab}}$ & $22.04^{\mathrm{c}}$ & $22.51^{\mathrm{bc}}$ & $23.49^{\mathrm{ab}}$ & $24.41^{\mathrm{a}}$ & 22.96 & 23.14 & 23.70 & 0.19 & $* *$ & $\dagger$ & NS \\
\hline Odd-chain FA & 2.20 & 2.13 & 2.19 & 2.14 & 2.13 & 2.11 & 2.15 & 2.22 & 0.028 & NS & NS & NS \\
\hline Branched-chain FA & $1.42^{\mathrm{b}}$ & $1.36^{\mathrm{b}}$ & $1.42^{\mathrm{b}}$ & $1.41^{\mathrm{b}}$ & $1.60^{\mathrm{a}}$ & $1.49^{\mathrm{a}}$ & $1.43^{\mathrm{a}}$ & $1.41^{\mathrm{b}}$ & 0.018 & $*$ & $* * *$ & NS \\
\hline$\Sigma \mathrm{n}-6$ & $2.58^{\mathrm{ab}}$ & $2.98^{\mathrm{a}}$ & $2.87^{\mathrm{a}}$ & $2.75^{\mathrm{a}}$ & $2.15^{\mathrm{b}}$ & 2.69 & 2.57 & 2.74 & 0.065 & * & NS & NS \\
\hline$\Sigma \mathrm{n}-3$ & $0.55^{\mathrm{c}}$ & $0.68^{\mathrm{ab}}$ & $0.62^{\mathrm{b}}$ & $0.75^{\mathrm{a}}$ & $0.67^{\mathrm{b}}$ & $0.71^{\mathrm{a}}$ & $0.62^{\mathrm{b}}$ & $0.62^{\mathrm{b}}$ & 0.016 & * & *** & NS \\
\hline$\Sigma \mathrm{n}-6 / \Sigma \mathrm{n}-3$ & $4.78^{\mathrm{a}}$ & $4.58^{\mathrm{a}}$ & $4.66^{\mathrm{a}}$ & $3.71^{\mathrm{b}}$ & $3.25^{\mathrm{c}}$ & $3.84^{\mathrm{b}}$ & $4.28^{\mathrm{ab}}$ & $4.47^{\mathrm{a}}$ & 0.122 & ** & $* *$ & NS \\
\hline trans-11 C18:1/trans-10 C18:1 & $1.84^{\mathrm{b}}$ & $1.55^{\mathrm{c}}$ & $1.72^{\mathrm{b}}$ & $1.94^{\mathrm{b}}$ & $3.22^{\mathrm{a}}$ & $0.98^{\mathrm{a}}$ & $0.90^{\mathrm{ab}}$ & $0.76^{\mathrm{b}}$ & 0.092 & $* *$ & * & NS \\
\hline cis-9 C14:1/C14:0 & 0.10 & 0.09 & 0.09 & 0.10 & 0.09 & $0.09^{\mathrm{b}}$ & $0.10^{\mathrm{a}}$ & $0.09^{\mathrm{b}}$ & 0.001 & NS & $* * *$ & NS \\
\hline
\end{tabular}

${ }^{\mathrm{a}-\mathrm{c}}$ Different superscript letters within the same row indicate differences among systems or periods $(P<0.05)$

${ }^{1} \mathrm{CCH}$ = farms feeding lactating cows with a high proportion of commercial concentrate mix; $\mathrm{CCM}=$ farms feeding lactating cows with a medium proportion of commercial concentrate mix; $\mathrm{CC} 0$ = farms feeding lactating cows without commercial concentrate mix; $\mathrm{HF}$ = farms feeding lactating cows with a high proportion of forages; $\mathrm{G}=$ farms feeding lactating cows with fresh herbage cut and fed indoors.

${ }^{2} \mathrm{P} 1=$ June to July; P2 = November to December; P3 = February to March

$* * * P<0.001 ; * * P<0.01 ; * P<0.05 ; \dagger=P<0.1$ 
Trans Isomers of C18:1. The CCM and CC0 milk had greater concentrations of trans-4 C18:1, trans-9 $\mathrm{C} 18: 1$, and trans- 12 + cis- $6 \mathrm{C} 18: 1$ than $\mathrm{CCH}, \mathrm{HF}$, and $\mathrm{G}$ milk. The $\mathrm{CCM}$ and $\mathrm{CC} 0$ and $\mathrm{CC} 0, \mathrm{CCH}$, and $\mathrm{HF}$ milk had similar concentrations of trans-6/7/8 C18:1 and trans-10 C8:1. However, CCM milk had greater concentrations of these $2 \mathrm{FA}(+0.09$, and $+0.26 \mathrm{~g} / 100$ $\mathrm{g}$ of $\mathrm{FA}$, respectively) than $\mathrm{CCH}$ and $\mathrm{HF}$ milk. The lowest values for those $2 \mathrm{FA}$ were observed for $\mathrm{G}$ milk $(-0.12$ and $-0.41 \mathrm{~g} / 100 \mathrm{~g}$ of FA, respectively, compared with CCM milk). The lowest concentrations of trans-11 C18:1 were found in CCH milk $(-0.28 \mathrm{~g} / 100 \mathrm{~g}$ of FA compared with CCM and CC0 milk). The CCM milk also had greater concentration of trans-11 C18:1 than HF and G milk $(+0.18 \mathrm{~g} / 100 \mathrm{~g}$ of FA). The sum of trans 18:1 isomers and of the total trans FA showed the same trend as trans-6/7/8 C18:1 and trans-10 C8:1. The trans-10 C18:1/trans-11 C18:1 ratio was the greatest in $\mathrm{G}$ milk and the lowest in CCM milk $(+1.39$, and -0.93 than $\mathrm{CCH}, \mathrm{CC} 0$, and $\mathrm{HF}$ milk, respectively).

A greater concentration of trans-5 C18:1 was observed in P2 than in P3, whereas the opposite trend was found for trans-6/7/8 C18:1 concentration. Milk from P3 had the greatest concentrations of trans- $12+$ cis- 6 C18:1, whereas the trans-13 C18:1 concentration and trans-10 C18:1/trans-11 C18:1 ratio were the lowest.

Cis Isomers of C18:1. The CCM and CC0 milk had greater concentrations of cis-9 $\mathrm{C} 18: 1$ than $\mathrm{CCH}$ and $\mathrm{G}$ milk $(+2.06 \mathrm{~g} / 100 \mathrm{~g}$ of $\mathrm{FA})$, with intermediate values for HF milk. The CCM milk had a greater concentration of cis-14 $\mathrm{C} 18: 1$ than $\mathrm{CCH}$ and $\mathrm{G}$ milk, and of cis-10 C18:1, cis-12 C18:1, and cis-16 C18:1 than HF and $\mathrm{G}$ milk. The $\mathrm{CC} 0$ and HF milk also had greater concentration of cis-10 $\mathrm{C} 18: 1$ than $\mathrm{G}$ and $\mathrm{CCH}$ milk, whereas CCM milk was also richer in cis-12 C18:1 than CCH milk. Greater concentrations of cis-11 C18:1 and cis-13 C18:1 were found in CCM and CC0 milk than in G milk. The sum of cis isomers of C18:1 showed the same trend as cis-9 C18:1. The milk in P2 was richer in cis-10 C18:1, whereas the milk in P3 was richer in cis-14 C18:1 and cis-15 C18:1. Lower concentrations of cis-16 C18:1 were also found in P1, than in P2 and P3.

Other MUFA. The G, HF, and $\mathrm{CCH}$ milk had greater concentrations of cis-9 $\mathrm{C} 10: 1$ and cis-9 C12:1 than CCM and CC0 milk. The sum of MUFA was greater in $\mathrm{CCM}$ and $\mathrm{CC} 0$ milk than in $\mathrm{CCH}$ and $\mathrm{G}$ milk $(+3.81 \mathrm{~g} / 100 \mathrm{~g}$ of FA), and was greater in CCM than in HF milk $(+2.68 \mathrm{~g} / 100 \mathrm{~g}$ of FA).

The cis-9 C12:1, cis-9 C16:1, and cis-9 C19:1 showed the lowest concentrations in milk in $\mathrm{P} 1$, and cis-11 C20:1 the greatest in P2. The cis-9 C14:1 concentration was greater in $\mathrm{P} 2$ than in $\mathrm{P} 1$, with intermediate values in P3. The cis-9 C14:1/C14:0 ratio was greater in P2 than in P1 and P3.
$\boldsymbol{P U F A}$. The C18:2n-6 concentration was greater in CCM, CC0, and HF than in G milk $(+0.71 \mathrm{~g} / 100 \mathrm{~g}$ of FA), with intermediate values in $\mathrm{CCH}$ milk. The CCM milk had greater concentrations of cis-9,trans-13 C18:2 and cis-9,trans-12 + cis-9,trans-14 C18:2 than $\mathrm{CCH}$, $\mathrm{HF}$, and $\mathrm{G}$ milk $(+0.10$, and $+0.03 \mathrm{~g} / 100 \mathrm{~g}$ of FA, respectively). Greater concentrations of these FA were also found in $\mathrm{CC} 0$ than in $\mathrm{G}$ milk $(+0.07$, and +0.02 $\mathrm{g} / 100 \mathrm{~g}$ of FA, respectively). The concentration of cis9,trans-11 CLA was greater in CCM than in HF, G, and $\mathrm{CCH}$ milk $(+0.12 \mathrm{~g} / 100 \mathrm{~g}$ of FA). The $\mathrm{CCH}$ milk also had lower values of this FA than CCM and HF milk $(-0.09 \mathrm{~g} / 100 \mathrm{~g}$ of FA). The concentration of cis9,cis-11 CLA was greater in G than in CCM and HF milk, with intermediate values in the other milk. The $\mathrm{HF}$ milk was richer in $\mathrm{C} 18: 3 \mathrm{n}-3$ than $\mathrm{G}, \mathrm{CC} 0$, and $\mathrm{CCH}$ milk, with intermediate values for CCM milk. A lower concentration of this FA was also found in $\mathrm{CCH}$ than in $\mathrm{G}$ and $\mathrm{CC} 0$ milk. The HF and $\mathrm{G}$ milk had greater concentrations of $\mathrm{C} 20: 5 \mathrm{n}-3$ than $\mathrm{CCH}$ milk, with intermediate values in $\mathrm{CCM}$ and $\mathrm{CC} 0$ milk. A greater concentration of C22:5n-3 was found in HF milk, compared with $\mathrm{CCH}, \mathrm{CCM}$, and $\mathrm{CC} 0$ milk. The sum of PUFA and the sum of n-6 FA were greater in $\mathrm{CCM}, \mathrm{CC} 0$, and HF than in G milk $(+0.91$ and $+0.72 \mathrm{~g} / 100 \mathrm{~g}$ of $\mathrm{FA})$, with intermediate values in $\mathrm{CCH}$ milk. The concentration of the sum of total n-3 FA was greater in HF than in $\mathrm{G}, \mathrm{CC} 0$, and $\mathrm{CCH}$ milk $(+0.14 \mathrm{~g} / 100 \mathrm{~g}$ of FA), with intermediate values for CCM. Lower concentrations in total n-3 FA were also found in $\mathrm{CCH}$ than in $\mathrm{G}$ and CC0 milk (-0.09 g/100 g of FA). Consequently, the ratio between total n-6 and total n-3 FA was greater in $\mathrm{CCH}$ (4.78), CCM (4.58), and CC0 (4.66) milk than in $\mathrm{HG}$ (3.71) and G milk (3.25), with the ration in G being lower than in HF.

The milk in P3 had greater concentration of cis9,trans-13 C18:2 and cis-9,trans-12 + cis-9,trans-14 $\mathrm{C} 18: 2$ than in $\mathrm{P} 1$, with intermediate values in $\mathrm{P} 2$. The ratio between total n- 6 and total n-3 FA showed the same trend. The milk C18:3n-6, C20:2n-6, and C20:3n-6 concentrations were greater in P2 than in P3, with intermediate values in $\mathrm{P} 1$. The milk in $\mathrm{P} 1$ had greater concentrations of C18:3n-3, C22:5n-3, and the sum of n-3 FA, and lower concentrations of C20:5n-3 than in P2 and P3. The cis-9,cis-11 CLA, trans-11,trans-13 CLA, and trans-9,trans-11 CLA concentrations were greater in $\mathrm{P} 2$ than in $\mathrm{P} 1$ and $\mathrm{P} 3$ milk.

The results of the PCA performed on milk FA concentrations and production condition data are presented in Figure 1. The de novo preformed FA, C16:0, and the total SFA concentrations were positively correlated with milk fat content (Pearson's $r>0.62$ ) on the first principal component (33.0\% of total variance), whereas they were negatively correlated with soybean meal and 


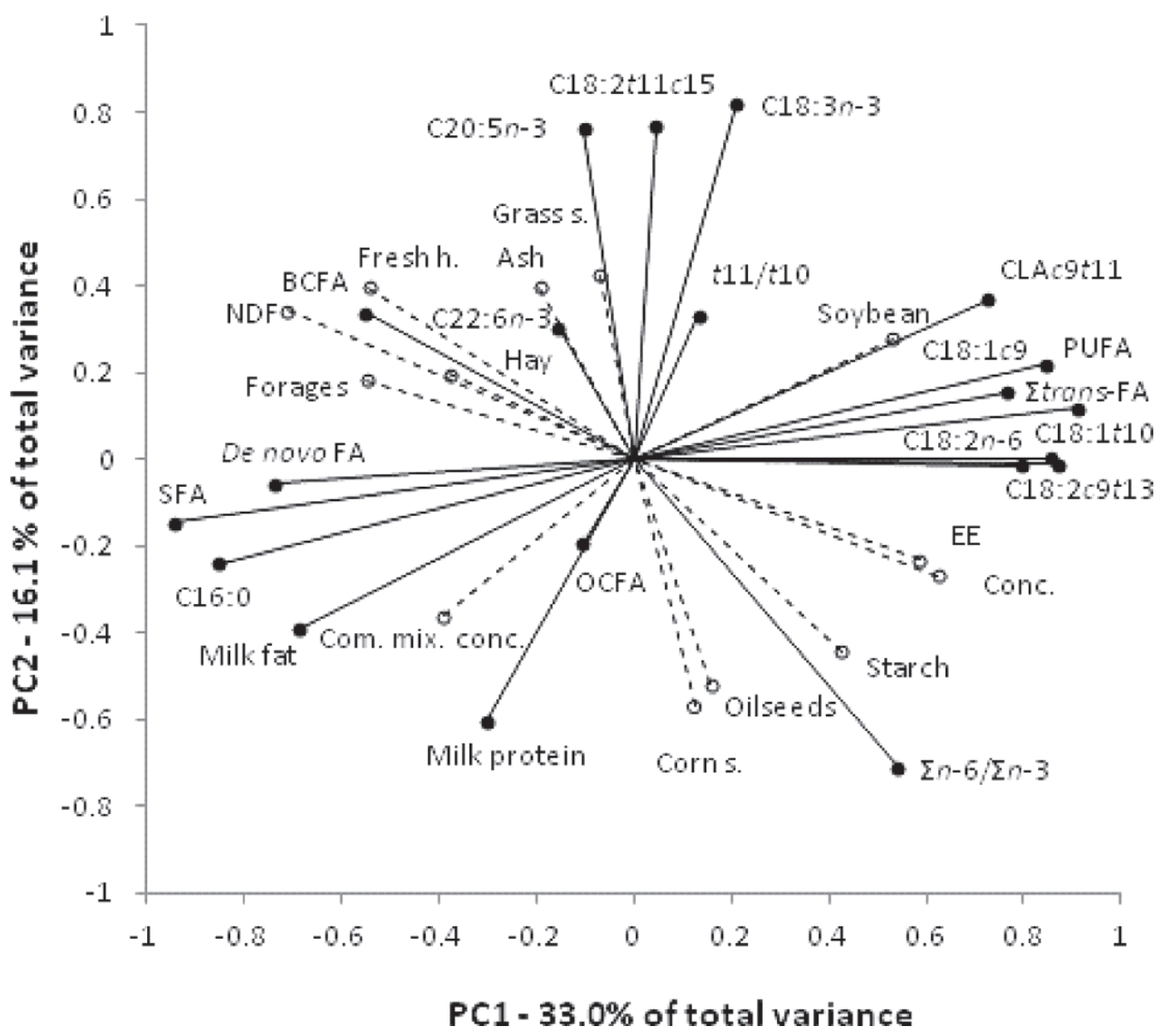

Figure 1. Principal components analysis (PCA) performed on milk composition (continuous lines and full dots) and production conditions (broken lines and empty dots). Plot of variable distribution projected on the 2 principal components $(\mathrm{PC} 1$ and $\mathrm{PC} 2)$. Conc. $=$ concentrate (without corn silage); Corn s. = corn silage; Fresh h. = fresh herbage; Grass s. = grass and legume silage; Com. mix. conc. = commercial concentrate mix; $\mathrm{BCFA}=$ branched-chain $\mathrm{FA} ; \mathrm{OCFA}=$ odd-chain $\mathrm{FA} ; \mathrm{EE}=$ ether extract; $\mathrm{CLA}=$ conjugated linoleic acid; $t=$ trans; $c=$ cis; $t 11 / t 10=$ trans-11 C18:1/trans-10 C18:1.

total concentrates (calculated considering corn silage fully as a roughage) proportions in the cow diet, and to diet EE content (Pearson's $\mathrm{r}<-0.42$ ). The soybean meal proportion in the cow diet was positively correlated with milk cis-9 C18:1, cis-9,trans-11 CLA, and total PUFA concentrations (Pearson's $r>0.39$ ) on the first principal component, whereas the commercial concentrate mix proportion was negatively correlated with cis-9,trans-11 CLA concentration (Pearson's $\mathrm{r}<-0.45$ ). The proportion of total concentrates (excluding corn silage grain) and diet EE content were positively correlated with milk C18:2n-6, cis-9,trans-13 18:2, trans-10 C18:1, and total trans FA concentrations (Pearson's r $>0.39$ ). The cis-9 C18:1, PUFA, and total trans FA concentrations were positively correlated with diet EE content (Pearson's $\mathrm{r}>0.43$ ). The milk protein content was correlated with the odd-chain FA concentration
(Pearson's $\mathrm{r}$ >0.39), whereas BCFA concentration was positively correlated with the proportion of hay, fresh herbage, and total forages in the cow diet and to the NDF content of the diet (Pearson's $r>0.37$ ). Furthermore, BCFA were negatively correlated with the proportion of total concentrates (excluding corn silage grain) in the cow diet and to diet EE content (Pearson's $\mathrm{r}<-0.36)$. The trans-11,cis-15 C18:2, C20:5n-3, and C18:3n-3 concentrations were positively correlated with the grass and legume silage proportions in the cow diet (Pearson's $\mathrm{r}>0.31$ ) on the second principal component ( $16.1 \%$ of total variance). The ratio between total $n-6$ and total n-3 FA was positively correlated with corn silage, oilseed proportions, diet starch, and EE contents (Pearson's r >0.42) and was negatively correlated with total forages and grass silage proportions in the cow diet (Pearson's $\mathrm{r}<-0.34$ ). 
Table 5. Farm efficiency parameters according to feeding system

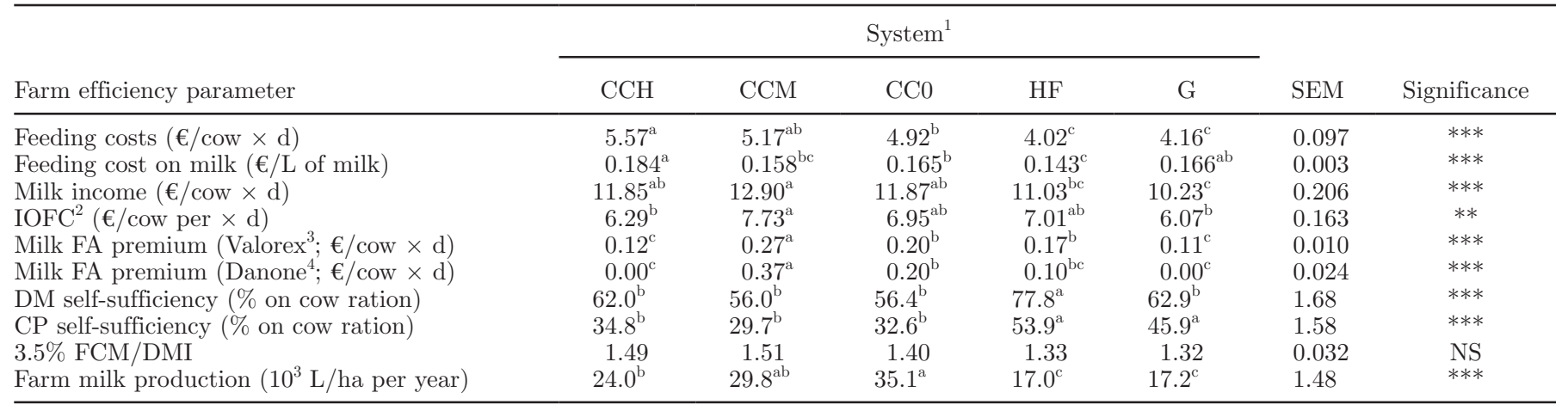

${ }^{\mathrm{a}-\mathrm{c}}$ Different superscript letters within the same row indicate differences among systems $(P<0.05)$.

${ }^{1} \mathrm{CCH}=$ farms feeding lactating cows with a high proportion of commercial concentrate mix; $\mathrm{CCM}=$ farms feeding lactating cows with a medium proportion of commercial concentrate mix; $\mathrm{CC} 0=$ farms feeding lactating cows without commercial concentrate mix; $\mathrm{HF}=$ farms feeding lactating cows with a high proportion of forages; $\mathrm{G}=$ farms feeding lactating cows with fresh herbage cut and fed indoors.

${ }^{2}$ Income over feed costs.

${ }^{3}$ Valorex SAS (Combourtillé, France).

${ }^{4}$ Danone (Tremblay-en-France, France).

${ }^{* * *} P<0.001 ;{ }^{* *} P<0.01 ; \dagger P<0.1$.

\section{Farm Efficiency Parameters and FA Supplementary Premiums}

Results about the farm efficiency parameters of the studied feeding systems are given in Table 5. Feeding costs were $€ 0.65 /$ cow $\times \mathrm{d}$ greater for $\mathrm{CCH}$ than for $\mathrm{CC} 0$, and 1.55 and $€ 1.41 /$ cow $\times$ d greater for $\mathrm{CCH}$ than $\mathrm{HF}$ and G, respectively. Feeding costs per liter of milk were the lowest in $\mathrm{HF}$ and the greatest in $\mathrm{CCH}$. The milk income per cow per day was greater in CCM than in $\mathrm{HF}(+€ 2.27 /$ cow $\times \mathrm{d})$, whereas the milk income of $\mathrm{G}$ was also lower than that of $\mathrm{CCH}$ and $\mathrm{CC} 0(-€ 1.43 / \mathrm{cow}$ $\times \mathrm{d})$. The IOFC were greater in $\mathrm{CCM}$ than in $\mathrm{CCH}$ and $\mathrm{G}(+€ 1.55 /$ cow $\times \mathrm{d})$, with intermediate values for $\mathrm{HF}$ and $\mathrm{CC} 0$. According to the Valorex FA premium calculations, all 20 farms had a milk FA composition achieving the required levels of the FA parameters to access the premium. The supplementary premium given for milk FA composition was greater in CCM than in $\mathrm{CC} 0$ and $\mathrm{HF}(+€ 0.09 / \mathrm{cow} \times \mathrm{d})$, and it was greater in $\mathrm{CC} 0$ and $\mathrm{HF}$ than in $\mathrm{G}$ and $\mathrm{CCH}(+€ 0.07 /$ cow $\times$ d). In contrast, according to the Danone system, only 9 of the 20 farms had milk FA composition achieving minimum levels required to access the premium: those included all $4 \mathrm{CCM}$ farms, 3 of the $4 \mathrm{CC} 0$ farms, and 2 of the $4 \mathrm{HF}$ farms, whereas none of farms in the $\mathrm{CCH}$ and $\mathrm{G}$ systems reached the minimum $\mathrm{FA}$ values to be eligible for the Danone premium. However, the average premium per farm according to the Danone system was about $50 \%$ greater than those calculated according to Valorex. The premium given for milk FA composition was greater in $\mathrm{CCM}$ than in $\mathrm{CC} 0$ and $\mathrm{HF}(+€ 0.22 /$ cow $\times d)$.
The feed DM produced on farm was greater in HF than in all the other systems $(+18.5 \%$ of cow diet $)$, whereas CP self-sufficiency was greater in $\mathrm{HF}$ and $\mathrm{G}$ than in $\mathrm{CCH}, \mathrm{CCM}$ and $\mathrm{CC} 0(+17.6 \%$ of cow diet $)$. The farm milk production per hectare was almost doubled in CC0 compared with HF and G (35.1 vs. 17.0 and $17.210^{5} \mathrm{~L} \times$ ha $\times$ yr), whereas it was intermediate for $\mathrm{CCM}$ and $\mathrm{CCH}$.

\section{DISCUSSION}

The studied farms and feeding systems can be considered representative of milk production in the Po Plain, where around $80 \%$ of Italian milk is produced (CLAL S.r.l., 2013). The 3 most-frequent dairy farming systems in the studied area are the most intensive systems: $\mathrm{CCH}, \mathrm{CCM}$, and $\mathrm{CC} 0$, which are based on corn silage feeding. These systems have low DM and CP selfsufficiencies and buy most of their dairy cow feeds off farm. This allows them to increase the amount of milk produced per hectare of farm cultivated area to 35,000 $\mathrm{L} /$ ha per year. These values are far greater than in the 6,000 to $19,000 \mathrm{~L} /$ ha per year range reported for other farming systems in Europe (Agabriel et al., 2007; McCarthy et al., 2011; Oenema et al., 2012). High levels of purchased feeds lead to a feeding cost ranging from $€ 0.158$ to $€ 0.184 / \mathrm{L}$ of milk. Those feeding systems only allow substantial IOFC to be achieved for milk yields exceeding 10,000 kg/cow per year. Because of increased corn and soybean prices over the last few years, costs of milk produced in systems with high proportions of purchased protein concentrate are no longer sustainable. Such circumstances encourage intensive dairy 
farms to adopt feeding systems that include increasing the proportion of homegrown forage. To avoid milk yield decreases, forages have to be of high nutritional quality. This alternative feeding system (HF) can be more economically competitive than $\mathrm{CCH}, \mathrm{CCM}$, or $\mathrm{CC} 0$, and even for a lower milk yield per cow. The use of homegrown forages in $\mathrm{HF}$ allows $\mathrm{DM}$ and $\mathrm{CP}$ self-sufficiencies to be increased and the feeding costs per liter of milk produced to be reduced by about 22 , 9, and $13 \%$ compared with $\mathrm{CCH}, \mathrm{CCM}$, and $\mathrm{CC} 0$, respectively. The G system included fresh herbage as a part of the TMR that was fed inside. Fresh herbage implies lower costs than conserved forages. However, herbage production is seasonal and its nutritive quality is difficult to manage for farmers (Finneran et al., 2011). Furthermore, alternative feed sources have to be used in the G system during the winter season, and this can lead to increased feeding costs. Milk production in $\mathrm{G}$ and HF forage-based systems relies more on farm cultivated land and makes these feeding systems more similar to the intensive or great input farming systems reported in the literature for other European countries (Slots et al., 2009; Stergiadis et al., 2012).

The studied systems highlighted great variations in milk FA profiles that were not expected for such intensive systems. The greater concentrations of de novo preformed FA, C16:0, and total SFA, and the greater milk fat content found in $\mathrm{CCH}$ and $\mathrm{G}$ than in the other systems could be related to the greater proportion of commercial concentrate mix in the cow diet, as shown by the PCA. The greater concentrations of BCFA in $\mathrm{G}$ milk could be explained by the greater proportion of roughage and the lower proportion of concentrate in lactating cow diets of $\mathrm{G}$ farms. These relationships between milk BCFA concentration and diet roughage, forages, and concentrate proportion and NDF content were also shown by the PCA. Fiber-rich diets could favor rumen cellulolytic bacteria, whose membrane lipids are the major source of BCFA in milk (Vlaeminck et al., 2006). A high roughage-to-concentrate ratio could explain the high ratio of trans-11 C18:1 to trans-10 C18:1 in $\mathrm{G}$ and a low roughage-to-concentrate ratio could explain its low value in CCM milk. Bauman and Griinari (2003) showed that a shift during ruminal biohydrogenation of dietary PUFA from the trans-11 C18:1 to trans-10 C18:1 pathway can occur in fiber-poor, and starch- and C18:2n-6-rich diets. According to Colman et al. (2010), a shift from trans-11 C18:1 to trans-10 C18:1 during the ruminal biohydrogenation could also increase milk concentrations of the other trans isomers of C18:1 and thus explain their greater concentration in CCM milk. The greater concentrations of total cis isomers of $\mathrm{C} 18: 1$ and cis-9 C18:1 in CCM and CC0 milk could be due to the greater proportion of soybean meal in the cow diet observed for these systems, as shown by the PCA. Soybean supplementation of cow diets induced milk richer in cis-9 C18:1 (Chilliard et al., 2007). The lower concentration of C18:2n-6 and the intermediate concentration of $\mathrm{C} 18: 3 \mathrm{n}-3$ in $\mathrm{G}$ milk could be explained by the lower starch content, by the greater proportions of hay, and by the presence of fresh herbage in the cow diet (Bauman and Griinari, 2003; Ferlay et al., 2008). Lower concentrations for the other nonconjugated C18:2 FA have also been found in G milk, as already shown by Ferlay et al. (2006) and by Chilliard et al. (2007) with similar diets. The greater concentration of cis-9,trans-11 CLA in CCM and CC0 milk in link with the greater values of trans-11 C18:1 are in agreement with Ferlay et al. (2006) and Chilliard et al. (2007), indicating the relationship between the substrate (trans-11 C18:1) desaturated by $\Delta^{9}$-desaturase to cis-9,trans-11 CLA in the mammary gland. The greater concentrations of C18:3n-3 and long-chain PUFA in HF milk are in agreement with Chilliard et al. (2007), who reported high concentrations of those FA in diets rich in forages The lower values of the ratio between the sums of $n-6$ and of $n-3$ FA in G and HF milk could be explained by the great forage proportion in the cow diet adopted by these systems (Chilliard et al., 2007).

Period had significant effects on several FA concentrations. Differences in milk FA profile among periods could depend on various factors such as minimal variations in cow feeding, according to seasonal fluctuations in the availability of forage and feeds on farm or on the market; and differences in nutritional quality within the same feed, which depends on agronomical or conservation practices. Furthermore, the lactation stage could also play a role in the milk FA profile (Palmquist et al., 1993).

Surprisingly, no significant variations in G milk were found among periods, even though the fresh herbage proportion in the cow diet was reduced to a great extent in P3. This trend could be due to the low proportion of fresh herbage and the great proportion of concentrate in the cow diet compared with the fresh herbage proportion reported in the literature to be sufficient to affect milk FA profile (about 30\% of DMI; Couvreur et al., 2006; Morales-Almaráz et al., 2010; Revello-Chion et al., 2012).

The concentrations of the main individual SFA and the sum of total SFA found in milk of all the feeding systems in our trial were lower than those reported in the literature for intensive farming systems (Slots et al., 2009). In the present study, the decrease in milk SFA concentration in favor of cis-9 C18:1 concentration could be related to the greater proportion of soybean meal and other protein-rich concentrates (as shown by the PCA) that are necessary to cover the protein 
requirements of dairy cow fed diets with a great proportion of corn silage. In other intensive farming systems in northern Europe presented by Slots et al. (2009), the protein supplementation with concentrates and soybean meal is usually lower because corn silage is partially or totally substituted by grass silage. The odd-chain $\mathrm{FA}$ and $\mathrm{BCFA}$ concentrations in $\mathrm{CCH}, \mathrm{CCM}$, and $\mathrm{CC} 0$ milk were about half of those reported by Ferlay et al. (2008) in milk from winter feeding with low proportions of corn silage. The concentrations of these FA found in $\mathrm{HF}$ and $\mathrm{G}$ milk were similar to those observed by the same authors in winter diets when hay and grass silage proportions on total roughage increased to at least $40 \%$. The trans-11 C18:1 concentrations observed in our milk were similar or lower than those found by several authors for milk from winter diets or indoor feeding in intensive farming systems in other European countries (Butler et al., 2008; Stergiadis et al., 2012) in which there was much more grass silage in the cow diet. Moreover, we found from 33 to $330 \%$ greater concentrations of trans-10 C18:1 than those reported by Ferlay et al. (2008) in winter diets with $60 \%$ corn silage in the total roughage. The elevated concentration of trans-10 C18:1 that was found in our study could be related to the greater starch content in cow diets (Bauman and Griinari, 2003) and to the concentrate proportion in the cow diet, as shown by the PCA. The concentrations of C18:2n-6 and cis-9,trans-11 CLA observed in our milk were greater and lower, respectively, than those reported by Butler et al. (2008) and Slots et al. (2009), for similar feeding systems. This could be due to the lower corn silage and greater grass silage proportions in the high-input farming systems described in these previously cited studies, the corn silage being richer in C18:2n-6 than other forages.

To verify the possibility of valorization of milk produced in these intensive farming systems based on certain FA concentrations, we tested the method of payment proposed by Valorex and by Danone, which calculate a milk FA supplementary premium, considering 3 parameters: (1) C18:3n-3 concentration, (2) SFA (excluding C18:0) concentration, and (3) the ratio between total isomers of $\mathrm{C} 18: 1$ and $\mathrm{C} 16: 0$ concentrations, and (1) C18:3n-3 concentration, (2) even-chain SFA concentration, and (3) ratio between total cis isomers of C18:1 and C16:0 concentrations, respectively. Concentration of SFA weighted the most for the FA supplementary premium in both calculation systems and most farms did not reach the concentration of C18:3n-3 or achieve a high enough ratio between total isomers of $\mathrm{C} 18: 1$ and $\mathrm{C} 16: 0$ for those measures to contribute to a premium. Thus, the greater supplementary premium/cow per day observed for CCM milk in applying both payment systems could be explained by the lower concentration of SFA in CCM milk. The CCM herds had the lowest roughage and the highest concentrate proportions in the cow diet, which could favor a higher frequency of subclinical rumen acidosis in those herds (Bauman and Griinari, 2003), and which could have a negative effect on de novo synthesis of FA and C16:0 (Colman et al., 2010). The low milk FA supplementary premium and its absence for $\mathrm{G}$ and $\mathrm{CCH}$ systems applying Valorex and Danone calculations, respectively, could be explained by the high SFA proportion in G and $\mathrm{CCH}$ milk, due to a greater proportion of commercial concentrate mix in the cow diet. The lipid component of commercial concentrate mixes (sometimes including palm oil, which is rich in C16:0) could have contributed to increased C16:0 and SFA concentrations in milk. Thus, high proportion of commercial concentrate mix may have made negligible the effect of inclusion of fresh herbage in the diet on C18:3n-3 concentration in G milk. The great proportion of forages in the HF diet and the low proportion of commercial concentrate mix resulted in a greater concentration of $\mathrm{C} 18: 3 \mathrm{n}-3$ in $\mathrm{HF}$ milk, increasing also the HF milk FA supplementary premium, and compensating for a slightly greater milk SFA concentration than CCM and CC0. Furthermore, the milk produced in HF system showed the greatest potential to improve the concentration milk FA having nutritional benefits through forage quality management. In particular, the n-6 FA:n-3 FA ratio was $<4$, which is closer to recent recommendations for human nutrition (Simopoulos, 2002). Values of the n-6 FA:n-3 FA ratio $<4$ were also observed for the $\mathrm{G}$ milk, but high C16:0 and SFA concentrations make the G milk FA profile less similar to overall recommendations for human nutrition. The applied FA supplementary premium calculations highlighted that the differences in milk FA profiles found in intensive dairy farming systems can result in differences in milk economic value. However, adaptations of premium calculations to the requirement of the local dairy industries are recommended. The total C18:1 isomers:C16 ratio, for example, is an important parameter for cheesemaking and butter production, being related to fat melting point and thus to butter spreadability or to cheese texture (Hurtaud et al., 2009; Coppa et al., 2011b). However, it seems to be negligible for milk destined to direct sale and consumption. Furthermore, other FA measures that have recently gained great interest for human nutrition, such as trans FA, BCFA, cis-9,trans-11 CLA, and n-6 FA:n3 FA ratio (Simopoulos, 2002; Givens, 2010; Kratz et al., 2013), were not taken into account by either of the FA premium calculations applied in the present research. The SFA, C18:3n-3, and the total C18:1 isomers: $\mathrm{C} 16$ ratio can be predicted by rapid and cheap infrared spectroscopy analysis, with promising results 
(Coppa et al., 2010; Soyeurt et al., 2011). However, infrared spectroscopy predictions for trans FA, BCFA, cis-9,trans-11 CLA, and n-6 FA:n-3 FA ratio need to be improved and up to now, these FA can be reliably analyzed only by expensive and time-consuming gas chromatography, not suitable for routine FA analysis. Thus, further improvements in rapid infrared analysis methods will be required, aiming to include trans FA, BCFA, cis-9,trans-11 CLA, and n-6 FA:n-3 FA ratio in FA supplementary premium calculations.

\section{ACKNOWLEDGMENTS}

This work was funded by the Regione Piemonte, Assessorato Qualità, Ambiente e Agricoltura, years 2010 to 2013 project "Miglioramento della qualità nutrizionale e della sicurezza alimentare e microbiologica della filiera lattiero-casearia in Piemonte." The authors contributed equally to the work described in this paper. The authors thank V. Chatellier (Valorex, Combourtillé, France) and R. Baes (InVivo, Paris, France) for kindly giving the information concerning FA supplementary premiums calculations.

\section{REFERENCES}

Agabriel, C., A. Cornu, C. Journal, C. Sibra, P. Grolier, and B. Martin. 2007. Tanker milk variability according to farm feeding practices: Vitamins A and E, carotenoids, color, and terpenoids. J. Dairy Sci. 90:4884-4896.

AOAC International. 2005. Official Methods of Analysis. 18th ed. AOAC International, Gaithersburg, MD.

Bauman, D. E., and J. M. Griinari. 2003. Nutritional regulation of milk fat synthesis. Annu. Rev. Nutr. 23:203-227.

Butler, G., J. H. Nielsen, T. Slots, C. Seal, M. D. Eyre, R. Sanderson, and C. Leifert. 2008. Fatty acid and fat-soluble antioxidant concentrations in milk from high- and low-input conventional and organic systems: seasonal variation. J. Sci. Food Agric. 88:1431-1441.

Chilliard, Y., F. Glasser, A. Ferlay, L. Bernard, J. Rouel, and M. Doreau. 2007. Diet, rumen biohydrogenation and nutritional quality of cow and goat milk fat. Eur. J. Lipid Sci. Technol. 109:828855

CLAL S.r.l. 2013. Notizie dal mercato. Accessed Jan. 2013. http:// www.clal.it/.

Collomb, M., U. Bütikofer, R. Sieber, B. Jeangros, and J.-O. Bosset. 2002. Correlations between fatty acids in cows' milk fat produced in the lowland, mountain and highlands of Switzerland and botanical composition of the fodder. Int. Dairy J. 12:661-666.

Colman, E., W. B. Fokkink, M. Craninx, J. R. Newbold, B. De Baets, and V. Fievez. 2010. Effect of introduction of subacute ruminal acidosis on milk fat profile and rumen parameters. J. Dairy Sci. 93:4759-4773

Coppa, M., A. Ferlay, C. Leroux, M. Jestin, Y. Chilliard, B. Martin, and D. Andueza. 2010. Prediction of milk fatty acid composition by near infrared reflectance spectroscopy. Int. Dairy J. 20:182189.

Coppa, M., A. Ferlay, F. Monsallier, I. Verdier-Metz, P. Pradel, R. Didienne, A. Farruggia, M. C. Montel, and B. Martin. 2011a. Milk fatty acid composition and cheese texture and appearance from cows fed hay or different grazing systems on upland pastures. J. Dairy Sci. 94:1132-1145.

Coppa, M., I. Verdier-Metz, A. Ferlay, P. Pradel, R. Didienne, A. Farruggia, M. C. Montel, and B. Martin. 2011b. Effect of different grazing systems on upland pastures compared with hay diet on cheese sensory properties evaluated at different ripening times. Int. Dairy J. 21:815-822.

Couvreur, S., C. Hurtaud, C. Lopez, L. Delaby, and J. L. Peyraud 2006. The linear relationship between the proportion of fresh grass in the cow diet, milk fatty acid composition, and butter properties. J. Dairy Sci. 89:1956-1969.

Dewhurst, R. J., K. J. Shingfield, M. R. F. Lee, and N. D. Scollan. 2006. Increasing the concentrations of beneficial polyunsaturated fatty acids in milk produced by dairy cows in high-forage systems. Anim. Feed Sci. Technol. 131:168-206.

Ferlay, A., C. Agabriel, C. Sibra, C. Journal, B. Martin, and Y. Chilliard. 2008. Tanker milk variability in fatty acids according to farm feeding and husbandry practices in a French semi-mountain area. Dairy Sci. Technol. 88:193-215.

Ferlay, A., B. Martin, P. Pradel, J. B. Coulon, and Y. Chilliard. 2006. Influence of grass-based diets on milk fatty acid composition and milk lipolytic system in Tarentaise and Montbéliarde cow breeds. J. Dairy Sci. 89:4026-4041.

Finneran, E., P. Crosson, P. O'Kiely, L. Shalloo, P. D. Forristal, and M. Wallace. 2011. Economic modelling of an integrated grazed and conserved forages perennial ryegrass forage production system. Grass Forage Sci. 67:162-176.

Givens, D. I. 2010. Milk and meat in our diet: Good or bad for health? Animal 4:1941-1952.

Hurtaud, C., J. L. Peyraud, G. Michel, D. Berthelot, and L. Delaby. 2009. Winter feeding systems and dairy cow breed have an impact on milk composition and flavor of two Protected Designation of Origin of French cheeses. Animal 3:1327-1338.

Kratz, M., T. Baars, and S. Guyenet. 2013. The relationship between high-fat dairy consumption and obesity, cardiovascular, and metabolic disease. Eur. J. Nutr. 52:1-24. http://dx.doi.org/10.1007/ s00394-012-0418-1.

Loor, J. J., A. Ferlay, A. Ollier, M. Doreau, and Y. Chilliard. 2005. Relationship among trans and conjugated fatty acids and bovine milk fat yield due to dietary concentrate and linseed oil. J. Dairy Sci. 88:726-740.

Lucas, A., C. Agabriel, B. Martin, A. Ferlay, I. Verdier-Metz, J.-B. Coulon, and E. Rock. 2006. Relationships between the conditions of cow's milk production and the contents of components of nutritional interest in raw milk farmhouse cheese. Lait 86:177-202.

McCarthy, B., L. Delaby, K. M. Pierce, F. Journot, and B. Horan 2011. Meta-analysis of the impact of stocking rate on the productivity of pasture-based milk production systems. Animal 5:784794.

Mertens, D. R. 2009. Maximizing forage use by dairy cows. WCDS Adv. Dairy Technol. 21:303-319.

Morales-Almaráz, E., A. Soldado, A. González, A. Martínez-Fernández, I. Domínguez-Vara, B. de la Roza-Delgado, and F. Vicente. 2010. Improving the fatty acid profile of dairy cow milk by combining grazing with feeding of total mixed ration. J. Dairy Res. $77: 225-230$.

Oenema, J., M. van Ittersum, and H. van Keulen. 2012. Improving nitrogen management on grassland on commercial pilot dairy farms in the Netherlands. Agric. Ecosyst. Environ. 162:116-126.

Palmquist, D. L., A. D. Beaulieu, and D. M. Barbano. 1993. Feed and animal factors influencing milk fat composition. J. Dairy Sci 76:1753-1771.

Revello-Chion, A., E. Tabacco, G. Battelli, F. Righi, A. Quarantelli, D. Giaccone, and G. Borreani. 2012. Effects of fresh forage inclusion in diet of high performance dairy cows on milk production and composition. Grassl. Sci. Eur. 17:405-407.

Revello-Chion, A., E. Tabacco, D. Giaccone, P. G. Peiretti, G. Battelli, and G. Borreani. 2010. Variation of fatty acid and terpene profile in mountain milk and "Toma Piemontese" cheese as affected by diet composition in different seasons. Food Chem. 121:393-399.

Simopoulos, A. P. 2002. The importance of the ratio of omega-6/omega-3 essential fatty acids. Biomed. Pharmacother. 56:365-379.

Slots, T., G. Butler, C. Leifert, T. Kristensen, L. H. Skibsted, and J. H. Nielsen. 2009. Potentials to differentiate milk composition by different feeding strategies. J. Dairy Sci. 92:2057-2066. 
Soyeurt, H., F. Dehareng, N. Gengler, S. McParland, E. Wall, D. P. Berry, M. Coffey, and P. Dardenne. 2011. Mid-infrared prediction of bovine milk fatty acids across multiple breeds, production systems, and countries. J. Dairy Sci. 94:1657-1667.

Stark, A. H., M. A. Crawford, and R. Reifen. 2008. Update on Q-linolenic acid. Nutr. Rev. 66:326-332.

Stergiadis, S., C. Leifert, C. J. Seal, M. D. Eyre, J. H. Nielsen, M. K. Larsen, T. Slots, H. Steinshamn, and G. Butler. 2012. Effect of feeding intensity and milking system on nutritionally relevant milk components in dairy farming systems in the north east of England. J. Agric. Food Chem. 60:7270-7281.

Sterk, A., B. E. O. Johansson, H. Z. H. Taweel, M. Murphy, A. M. van Vuuren, W. H. Hendriks, and J. Dijkstra. 2011. Effects of forage type, forage to concentrate ratio, and crushed linseed supplementation on milk fatty acid profile in lactating dairy cows. J. Dairy Sci. 94:6078-6091.

Van Soest, P. J., J. B. Robertson, and B. A. Lewis. 1991. Methods for dietary fiber, neutral detergent fiber, and nonstarch polysaccharides in relation to animal nutrition. J. Dairy Sci. 74:3583-3597.

Vlaeminck, B., V. Fievez, A. R. J. Cabrita, A. J. M. Fonseca, and R J. Dewhurst. 2006. Factors affecting odd- and branched-chain fatty acids in milk: A review. Anim. Feed Sci. Technol. 131:389-417.

Wolf, C. A. 2012. Dairy farmer use of milk price risk management tools. J. Dairy Sci. 95:4176-4183. 